\title{
16 Nisan Referandum Sürecinde Başkanlık Sistemi Tartışmalarının Türk Basınına Yansımaları
}

\author{
EZGI ÇAKIR* \\ ezgcakir@gmail.com \\ ORCID ID: 0000-0002-6910-3417
}

Öz: Türkiye’nin siyasal tarihine bakıldiğında Özal ile başlayan, Demirel ile devam eden alternatif hükümet sistemi tartışmaları siyasi liderlerin yapmış olduğu açıklamalarla medya gündeminde yerini aldiğı görülmektedir. Son olarak Ak Parti Hükümeti döneminde yoğun bir şekilde sürdürülen bu tartışmalarla birlikte 16 Nisan Referandumu'na gidilmiştir. Özellikle başkanlık sistemi gündeminin yaratılmasında haber aktörleri olarak siyasi liderlerin oldukça büyük etkiye sahip oldukları, bununla beraber medya kuruluşlarının haberlerinde benimsemiş oldukları ideolojik yayın çizgisi doğrultusunda haber aktörlerine daha kısıtl ya da kapsaml, olumlu ya da olumsuz yer verildiği varsayılmaktadır. Bu kapsamda, gündem belirleme kuramı temelinde 16 Nisan referandumu öncesi, 11 Ekim 2016 -10 Aralık 2016 tarihleri arasında geçen süreçte başkanlık sistemi tartışmalarının Sabah, Hürriyet ve Sözcü gazetelerinin vitrin sayfalarına yansıması nicel ve nitel değerlendirmeyi barındıran içerik analiz yöntemiyle incelenmiştir.

Anahtar Kelimeler: Başkanlık sistemi, Gündem belirleme, Referandum.

\section{Giriş}

Bireylerin dünyasını tasarlama olanağına sahip olan medyanın gündeminde herhangi bir konunun diğer konulardan sıyrılarak gündemin ilk sıralarına yerleşmesinde etkili olan unsurun ne olduğu sorusu uzun yıllar yapılan akademik çalışmalara konu oluşturmuştur.

1960’lı y1llara kadar W. Lippmann, N. Long, K. Lang ve G. Lang, B. Cohen gibi gündem belirleme üzerine yapılan pek çok araştırmada öncü isimler ortaya çıksa da belli bir paradigmanın ortaya çıkışı ancak 1970'li yıllarda sağlanabilmiştir. Gündem belirleme üzerine ilk sistematik çalışma 1972 yılında McCombs ve Shaw tarafından yapılmıştır. Fakat yapılan çalışmada gündemin kim tarafından belirlendiği sorusu tatmin edici şekilde yanıtlanamamıştır. Gündem belirlemenin kitle iletişim araçları tarafından mı, toplumdaki bireylerin ve onların ihtiyaçları tarafından mı, yoksa kitle iletişim araçlarına kaynak olan kurumsallaşmış seçkinler tarafından mı başlatıldığını ortaya koyma konusunda belirsizliklerin yaşandığı görülmektedir.

\footnotetext{
* Marmara Üniversitesi, Sosyal Bilimler Enstitüsü, Gazetecilik Doktora Programı Öğrencisi.
} 
Türkiye'de ideal yönetim sistemi arayışı yıllar boyunca süregelen tartışmalara neden olmuştur. Ülkemizde zaman zaman yaşanan siyasi kriz dönemlerinde siyasetçilerin demeçlerinde yeniden alevlenen bu tartışmalar sadece vatandaşların değil aynı zamanda akademisyenlerin, iş adamlarının ve medya kuruluşlarının gündeminde uzun süre yerini muhafaza etmiştir. Yapılan tartışmalarda yürütme erkinin gücünü sınırlayan istikrarsızlığa karşı kuvvetler ayrılığı mekanizmasının temel bağlamından ayrılarak yürütme erkinin daha ön planda olması gerektiği savunulmaktadır.

Yaklaşık on dört yıldır sistem değişikliği özel olarak da başkanlık sistemi üzerinden yapılan bu tartışmalar siyasal gündemde, medya gündeminde medya aracılığıyla da kamu gündeminde en fazla konuşulan konuların arasında yer aldığı görülmektedir. Başkanlık sistemi tartışmalarının son dönemdeki mimarı ise Milliyetçi Hareket Partisi (MHP) Genel Başkanı Devlet Bahçeli olmuştur. Devlet Bahçeli, parti grup toplantısında sistem değişikliğine dair yapmış olduğu açıklamasıyla bir uzlaşma penceresi açarak sisteme geçiş sürecinin adımlarının atılmasını sağlamıştır.

Bu çalışmada, gündem belirleme kuramı temelinde başkanlık sistemi tartışmalarının günümüzde siyasi liderlerinin açıklamalarında daha sık belirgin hale gelmesiyle birlikte ülkemizdeki ulusal yazılı basın tarafından nasıl ele alındığının ortaya konulması amaçlanmıştır.

Böyle bir çözümlemenin yapılması var olan politik ortamda yer alan başkanlık sistemi tartışmalarının medya üzerinden araçsallaştırılışına ışık tutarak, politik tartışmanın gazetelerde nasıl yansıtıldı̆̆ı, hangi kavramlar üzerinden tanımlandığının ortaya koyacaktır. Herhangi bir konunun medya gündeminde diğer olaylardan siyrılarak üst sıralara yerleştirilmesinde siyasi figürlerin ya da parti örgütlerinin ne derecede etkili olduğu; haber aktörü olarak siyasi liderlerin tek başına toplumdaki herhangi bir problemi dile getirerek o sorunu medya gündemine yerleştirip yerleştirmediğini ölçümlemek araştırmanın hedefleri arasında yer almaktadır.

Araştırmanın başlangıç tarihi MHP Genel Başkanı Devlet Bahçeli'nin parti grup toplantısında yapmış olduğu konuşmanın ardından tartışmaların hız kazandığı 11 Ekim 2016 olmuştur. MHP ile Ak Parti’nin (AKP) aralarında sağlamış olduğu mutabakat sonucu Anayasa değişikliği teklifinin 10 Aralık 2016 tarihinde TBMM'ye sunulması ise çalışmanın bitiş tarihi olarak belirlenmiştir. Araştırmada gazetelerin belirlenmesindeki kriter; Türk basınında ulusal çapta günlük olarak yayın yapan gazetelerden en yüksek tiraja sahip üç gazetenin kitlelere kolaylıkla ulaşması, görünür olması tercih sebebi olmuştur. Bunun yanı sıra seçilen üç gazetenin birbirlerinden farklı ideolojik çizgilere ve farklı medya yayın gruplarına ait olması bir diğer belirleyici özelliği oluşturmaktadır. Araştırmanın sınırlılığı kapsamında belirlenen Hürriyet, Sabah ve Sözcü gazetelerinin ilk sayfalarında ilgili konunun nasıl ele alındığı, haber metinlerinin nasıl inşa edildiği; gündem belirleme araştırmalarında yaygın olarak kullanılan yöntemlerden biri olan içerik analizi tekniğinin ışı̆̆ında ortaya konulması amaçlanmıştır.

Uzun yıllar boyunca medya gündemini meşgul eden sistem değişikliği tartışmalarının yaratılmasında parti kurumlarının ya da haber aktörleri olarak siyasi liderlerin 
tek başına medya gündemini başkanlık yönünden belirlemede etkin güç oldukları savı çalışmanın en önemli varsayımları arasında yer almaktadır.

1. Siyasi liderlerin yapmış olduğu açıklamalar medya gündeminin belirlenmesinde etkilidir.

1.1. Parti kurumlarının politikaları doğrultusunda dile getirilen sorunlar ulusal gazetelerin gündemini belirlemede tek başına yeterlidir.

1.2. Ulusal medya gündeminin oluşturulmasında ülke başkanın etkin bir rolü olduğu, bu süreçte en fazla haber kaynağı olarak Başbakan’a yer verildiği varsayılmaktadir.

2. Medya grupları benimsemiş oldukları ideolojik kimlikler doğrultusunda haber metinlerini oluştururken haber aktörlerine daha kısıtlı ya da daha kapsamlı yer vermektedir. İlgili konunun haberleştirilmesinde ise olumlu ya da olumsuz, destek ya da eleştiriye yönelik bir tutum sergiledikleri varsayılmaktadır.

\section{Gündem Belirleme Kuramı}

Gündem belirleme yaklaşımında, medyanın toplumsal bir olaya verdiği önem derecesiyle medyanın iletilerine maruz kalan bireylerinde aynı olaya verecekleri önem derecesinin eş değerde olduğu ileri sürülmektedir. Bireyler, içerisinde yaşadığ dünyada toplumdaki bütün olayları algılamada yeterli değillerdir, bu nedenle medyanın iletilerine ihtiyaç duymaktadırlar. Medya bilgilendirme işlevini sağlarken, herhangi bir olay hakkında o konuya ayırdığı yerin ve zamanın büyüklüğü aynı zamanda bireylerinde o olay hakkındaki konuların önem derecesini belirlemektedir. Bu süreçte bireylerin toplumsal olaylar hakkındaki görüşleri değiştirilmekte ya da yeniden inşa edilmektedir. Dolayısıyla bir süre sonra medyanın gerçeği, bireylerin gerçeğine dönüşmektedir.

Kitle iletişim araçlarının mevcut etkileri üzerinde çalışan gündem koyma yaklaşımı "haberdar etme" ya da "farkında olma" ve "bilme" aşamalarını kapsayan "bilişsel etkiler" üzerine odaklanmaktır. Bu yaklaşımının önde gelen isimlerinden McCombs ve Shaw’ın ifadesine göre; iletişim araçlarının mesajlarına maruz kalmakla başlayan etkiler zincirinin bir basamağını "haber etme" ya da "farkındalık yaratma" aşaması oluşturmaktadır. Yani bu aşamada bireyler medyayı takip etmeseler bile medyanın iletilerine maruz kalarak çevrelerinde olup bitenlerin farkına varıp haberdar olmaktadırlar. Ardından bireyler, önemi medya tarafından ön plana çıkartılıp sunulan konu ya da problemler hakkında daha yüksek oranda enformasyon edinmeye başlayarak "bilgi" ya da "bilişsel etkiler" aşamasına ulaşmaktadır. Son olarak "tutum değişikliği" ve "davranış değişikliği” basamaklarına ulaşarak tüm adımlar tamamlanmaktadır. Birbirleriyle sıkı bir şekilde bağlı olan bu süreç, gündem belirlemenin çıkış noktasını oluşturmaktadir ${ }^{1}$.

Medya kullanıcılarına, sıklıkla bir konu ya da olay hakkında herhangi bir düşünceye sahip olmadıkları bilgileri vermektedir. Dolayısıyla kullanıcılar üzerinde oluşan

1 Erkan Yüksel, Medyanın Gündem Belirleme Gücü, Konya: Çizgi Kitabevi Yayınları, 2001, s.22. 
etkiler tutum değişikliklerinde değil de, gündem belirleme durumunda ortaya çıkmaktadır. Kitle iletişim araçları tarafından aktarılan bilgilere yönelik uyanan ilgilerin, bireylerin gerçekliği doğrudan gözlemlediği ve yaşadığ aracılığıyla artmadığı görülmektedir. Bireylerde ilgi uyandıran gerçekliğin büyük bir kısmı dolaylı bir şekilde medya tarafından aktarıldığı belirlenmiştir. Kitle iletişim araçlarının gerçekliği tanımlamakta, yeniden inşa etmekte ve üretmekte kullanıcılara "medyatik gerçeklik" temelinde kendi tutumlarını aktardığı ileri sürülmektedir².

Gündem belirleme yaklaşımında, medyanın vurgu yaptığı konular ile izleyicilerin bu konulara ilgi göstermelerinin arasında nedensel bir ilişki kurulmaktadır. İletişim araçlarının bir konuya yer verdiği sıklık derecesi, haber içeriklerinin uzunlukları hatta haber başlığının genişliği ya da sayfada yer alan konumu gibi unsunlar gündeme taşınan bir olayın ne derecede bir öneme sahip olduğunun algılanmasında etkili olmaktadir ${ }^{3}$.

Gündem belirleme ile ilgili yapılan çalışmaların tümünde, medya gündeminde yer alan önemli bir konunun aynı zamanda kamu gündeminde de aynı önem derecesine sahip olduğu ifade edilmiştir. Daha sonra yapılan çalışmalarda tek bir gündemin varlığından ziyade birçok gündemin bir zincir halinde varolduğu belirlenmiş; medya, kamu ve siyaset gündemi arasında ciddi bir etkileşim olduğu ortaya konulmuştur.

Siyasal gündem çalışmalarında "güç" kavramına vurgu yapan Smith, medya ve siyaset seçkinlerinin kendi aralarında gündemlerini öne çıkarmak ve birbirlerinin gündemlerini etkilemek için "güç oyunu” oynandığını ileri sürmektedir. Çoğunlukla seçkin kişilerin kazandığı bu oyunda seçkinler, istedikleri konunun gündemin üst sıralara yerleşmesini sağlamak için medyanın kontrolünü elinde bulundurmak istemektedirler ${ }^{4}$. Siyasi kurumlar medyayı, kendi fikirlerini topluma aktarma sürecinde bir araç olarak kullanıp halkı etki altına almayı hedeflemektedir. Medyada bir sorunu ya da konuyu sürekli olarak gündeme taşıyarak siyasal gündemi doğrudan etkileyebilmektedir. Yani siyasal gündemin, medya gündemi üzerinde aynı şekilde medya gündeminin de siyasal gündem üzerinde önemli etkisi olduğu görülmektedir. Kendi gündemlerini yaratmak için oluşturdukları bu çaba medya ve siyasal kurumları arasında sıkı bir ilişkiyi oluşturmaktadır.

\section{Türkiye'de Başkanlık Sistemi Tartışmaları}

Yalnızca Türkiye'ye özgü olmayan bu sistem arayışları, yeni demokrasilerde olduğu gibi eski demokrasilerde de rastlanabilmektedir. Alternatif yönetim sistemi arayışları gündemde yerini almasıyla birlikte mevcut sistem değişikliğini başarabilen devletlerin sayısı oldukça az orandadır ${ }^{5}$. Ülkemizde son yıllarda yoğun yaşanan

2 Hans Mathias Kepplinger, Medya Etki Araştırmaları, çev., Murat S. Çebi, Ankara: Alternatif Yayınları, 2003, s.52.

3 Banu Terkan, Gündem Belirleme Medya ve Siyasal Gündem Üzerine Bir Çalışma, Konya: Tablet Kitapevi, 2005, s.38.

4 Yüksel, Medyanın Gündem Belirleme, s.130.

5 Levent Gönenç, “Türkiye’de Hükümet Sistemi Değişikliği Tartışmaları Olanaklar ve Olasılıklar Üzerine Bir Çalışma Notu”, Teoman Ergül (der.), Başkanlık Sistemi, Ankara: Türkiye Barolar Birliği Yayınları, 2005, s.2. 
sistem arayışlarının temel nedenleri arasında "siyasal istikrarsızlık" gösterilmektedir. Yürütme erkini güçsüz kılan bu istikrarsızlığa karşı kuvvetler ayrılığı mekanizmasının temel bağlamından ayrılarak yürütme erkinin daha ön planda olması gerektiği savunulmaktadir.

Yaşanan hükümet istikrarsızlığı sorunlarının, cumhurbaşkanının doğrudan vatandaşlar tarafından seçilmesi aynı zamanda cumhurbaşkanın parlamentoyu fesih edebilmesi gibi başkanlık ve yarı başkanlık rejimlerine yaklaşan yetkilerinin verilmesiyle çözüme kavuşturulacağı düşünülmüştür6́

Başkanlık sistemi tartışmaları, 1961 Anayasası’nın zayıf yanlarının ortaya çıkmasıyla birlikte, devlet otoritesinde yaşanan aksaklıklar sonucu Türkiye gündemine girmiş olup 1980'li yıllara gelindikçe daha yoğun bir şekilde tartışılmaya başlanmıştır'. Ülke yönetimde yaşanan tıkanıklarının temel sebebi olarak 61 Anayasası'nın yürütme erkine gereken güçlü yetki tanımlamaları yapmadığı ve bu durumunda siyasi ortamda istikrarsızlıkları tetiklediği öne sürülmektedir.

1980 yılına gelindiğinde Tercüman Gazetesi’nin düzenlemiş olduğu “Anayasa Semineri"nde başkanlık ve yarı başkanlık rejimlerine geçiş tartışmaları daha yoğun bir şekilde başlamıştır. Seminere katılan bilim insanlarından bazıları Fransa’nın 1958 Anayasası’yla uyguladığı yarı başkanlık rejimine geçişi savunurken bazıları başkanlık rejimini savunmuşlardır. Belli bir kısım, demokratik parlamenter rejimin korunarak devamlılığının sağlanmasını bunun yanı sıra cumhurbaşkanına daha geniş yetkilerin tanınması gerekliliğini savunmuştur. 12 Eylül 1980 askeri müdahalesinin ardından 1982 Anayasası́nın hazırlanış sırasında hükümet sistemi tartışmaları yeniden gündeme gelmiştir. Başkanlık ve yarı başkanlık sisteminin aksine demokratik parlamenter sistemin korunarak cumhurbaşkanının görev ve yetki alanlarının genişletilmesi bütün kuruluşların savundukları ortak görüş olmuştur. Başta üniversiteler olmak üzere, birçok kurum ve kuruluş; başkanlık ve yarı başkanlık yönetim sistemlerinin Türkiye’nin Cumhuriyet geleneğiyle örtüşmeyeceğini ve ülke yönetimde olası bir despotizme kolaylıkla zemin oluşturabileceği gerekçesiyle açık bir şekilde itiraz etmişlerdir. Başkanlık ve yarı başkanlık sistemlerini savunan üyelerin azınlıkta kalınması üzerine cumhurbaşkanının Türkiye Büyük Millet Meclisi (TBMM) tarafından seçilmesine ve geniş yetkilerle tanınarak demokratik parlamenter hükümet sistemin devamlılığı korunmuştur ${ }^{8}$.

1982 Anayasasının yapım sürecinde Danışma Meclisi’nde devlet başkanının seçimi ve yetkilerine ilişkin yapılan yoğun tartışmalar sonucunda devlet başkanının halk tarafından seçilmesi ve geniş yetkilere sahip kılınması görüşü itibar görmemişse de, 1982 Anayasası 1961 Anayasasının öngördüğü saf parlamenter yapıdan uzaklaşarak parlamento tarafından seçilen Cumhurbaşkanına

6 Gülgün Tosun ve Tanju Tosun, Türkiye’nin Siyasal İstikrar Arayışı Başkanlık ve Yarı Başkanlık Sistemleri, İstanbul: Alfa Yayınları, 1999, s.2.

7 Samed Kurban, "Başkanlık Sisteminden Beklentiler ve Türkiye”, Yüksek Lisans Tezi, Dumlupınar Üniversitesi, 2014, s.121.

8 Serap Yazıcı, Başkanlık ve Yarı-Başkanlık Sistemleri Türkiye İçin Bir Değerlendirme, İstanbul: İstanbul Bilgi Üniversitesi Yayınları, 2013, s.159. 
parlamenter sistemdeki konumu ile bağdaşmayacak geniş yetkiler tanımıştır. $\mathrm{Bu}$ durum ise, 11. Cumhurbaşkanı'nın seçim sürecinde yaşanan krize dek bu şekilde devam etmiştir?.

\section{Turgut Özal Dönemi}

1983-1989 yılları arasında başbakanlık yaptığı dönemlerde sistem değişikliğine ilişkin görüşlerini sık sık gündeme getirerek başkanlık rejimi lehine tartışmaları başlatan ilk isim Turgut Özal olmuştur. Özal'ın 1987'de bir gazeteciyle yapmış olduğu bir söyleşisinde; Cumhurbaşkanının görev ve yetki tanımlamalarını, seçimi ve görev süresi üzerine yaptığı açıklamalarıyla tartışmaların merkezinde olmuştur ${ }^{10}$. Turgut Özal ile yakın ilişki içerisinde olanların aktardıklarına göre; Özal’ın asıl hedefi Amerikan tipi başkanlık rejimiydi fakat yarı başkanlık sistemi üzerinde savunmaları gerçek amaca ulaşmada bir adım olarak görülmekteydi ${ }^{11}$.

12 Eylül askeri müdahalesinin ardından sivil yaşama geçişle birlikte Turgut Özal genel başkanlığında tek başına iktidara gelen Anavatan Partisi (ANAP) güçlü bir başbakan profili oluşturmak istemesine karşın dönemin Cumhurbaşkanı Evren tarafından engellenmesi Özal'ın başkanlık rejiminde ısrarcı olmasının arkasında yatan sebepler arasında sayılmaktadır. Özal, tasarladığı birçok yeniliklerden, Bakanlar Kurulu’nda bulunacak üyelere kadar birçok konuda Cumhurbaşkanı Evren ile anlaşmazlıklara düşmüştür. Turan’a göre, Özal, Cumhurbaşkanlığı makamına kendisinden başka birinin seçilmesi halinde, hukuki ve protokol bakımından kendisinden önce olacak birini kabullenememesine ek olarak kendi gücünün sınırlandırılması endişesiyle cumhurbaşkanlığı seçimlerinden hemen önce başkanlık sistemini gündeme taşımış$\operatorname{tır}^{12}$. Cumhurbaşkanı görevine geldikten sonra tasarladığı reformları hayata geçirme aşamasında uygun bir uzlaşma ortamının oluşmaması sonucu yeniden başkanlık sistemi tartışmalarını başlatan isim olmuştur ${ }^{13}$.

Özal, istikrarlı bir yönetim alanında hükümetlerin ekonomik yeniliklere öncülük ettiğini ifade ederek, Atatürk'ten itibaren tek parti iktidarının olduğu yıllarda önemli gelişmelerin yakalandığını ve bu dönemlerde bir tür başkanlık sisteminin uygulandığını ileri sürmüştür.

Turgut Özal'ın, başkanlık sistemini kuvvetle savunmasının altında aralarında uzlaşmaya sağlayamayan koalisyon hükümetlerinin Türkiye’ye zaman kaybettirdiği düşüncesi yatmaktadır. Ayrıca ülkenin heterojen yapısına başkanlık sisteminin daha

9 Nur Uluşahin, “Türkiye’de Hükümet Sisteminin Niteliği ve Rejimin Başkanlık Sistemine Kaymasının Getireceği Tehdit ve Tehlikeler”, Hukuk ve İktisat Araştırmaları Dergisi. 3/1 (2011), s.30.

10 Erdal Onar, “Türkiye’nin Başkanlık ya da Yarı Başkanlık Sistemine Geçmesi Düşünülmeli mi?”, Teoman Ergül (der.), Başkanlık Sistemi, Ankara: Türkiye Barolar Birliği Yayınları, 2005, s.84-85.

11 Gamze Küçükoba, "Başkanlık Sistemi ve Türkiye’ye Uygunluğu Sorunsalı”, Yüksek Lisans Tezi, Dicle Üniversitesi, 2014, s.61.

12 İlter Turan, "Başkanlık Sistemi Sevdası: Zayıf Temelli Bir Özlem”, Teoman Ergül (der.), Başkanlık Sistemi, Ankara: Türkiye Barolar Birliği Yayınları, 2005, s.119.

13 Cemal Fedayi, “Mazi, Hal ve İstikbal Boyutlarıyla Başkanlık Sistemi”, Yeni Türkiye Dergisi, 51 (2013), s.121122. 
uyumlu olabileceğini, bunun yanında seçmenin belirlediği ülke bütünlüğünü temsil eden bir başkanla daha demokratik hale gelebileceklerini ileri sürmüştür. Bunlara ek olarak, Özal’ın "tek adam olma” isteği, Amerikan tipi başkanlık rejiminin her fırsatta dile getirmesinin arkasında yatan sebepleri arasında görülmektedir ${ }^{14}$.

Bu sistemin devlet yönetiminde istikrar sağlayacağı görüşünü savunan Özal’ın, Cumhurbaşkanlığı görevinin başındayken hayatını kaybetmesiyle birlikte başkanlık sistemi tartışmalarının Demirel dönemine kadar gündemden uzaklaştığı görülmektedir.

\section{Süleyman Demirel Dönemi}

Özal'ın ölümünden sonra 90'lı yıllardan itibaren hükümet sistemi arayışı tartışmalarına Cumhurbaşkanı Süleyman Demirel dâhil olmuştur. Son dört yıl içerisinde altı hükümetin görev aldığını asıl sorunun demokratik istikrar arayışı olduğunu ifade eden Demirel, "Yarı başkanlık sistemi veya başkanlık sistemi önermiyorum. Türkiye yarı başkanlık sistemini de tartışmalıdır, başkalık sistemini de. Ben bunların hiçbirisini önermiyorum. Benim aradiğım ve istediğim, işleyen bir devlet ve işleyen demokrasidir.” sözleriyle sisteme yönelik asıl isteğini ifade etmiştir ${ }^{15}$.

Demirel, her ne kadar mevcut hükümet sistemleri içerisinden bir modelin ülkeye uygulanması yönünde açıklamalar ifade etmediğini dile getirse de, başkanlık sistemine daha istekli olduğu anlaşılmaktadır. 9. Cumhurbaşkanı Demirel'in, 1999 yılında TBMM'de yaptığ 1 açılış konuşmasında;

Cumhurbaşkanı, iki turlu seçimle, halk tarafından seçilmelidir. Bana göre, yedi sene Cumhurbaşkanlığı uzundur ve cumhurbaşkanı beş sene için seçilmelidir; eğer, Meclisiniz muvafik görürse, iki defa seçilebilmelidir; ama mutlaka halk tarafından seçilmelidir. Bunun birtakım mahzurları vardır; ama maksadınız, eğer demokrasiyi güçlendirmekse, demokrasinin kurumlarına daha çok otorite kazandırmaksa, mutlaka halkın rızasına ve yetkisine cumhurbaşkanlığı makamını bırakmak lazımdır.

İfadeleriyle ülke yönetimindeki istikrasızlığın, siyasi aksaklıkların aşılabilmesi için Cumhurbaşkanının iki turlu seçimle vatandaşlar tarafından seçilmesi gerekliliğini yeniden gündeme getirmiştir. Fakat Demirel'in bu görüşleri güçlü bir destek bulamadığı için sonuca ulaşamamıştır ${ }^{16}$.

Demirel'in sistem değişikliğine yönelik yapmış olduğu açıklamaları, ülke gündeminde yoğun bir şekilde tartışma alanları yaratarak başkanlık ve yarı başkanlık sistemlerinin Türkiye’ye uygunluğu incelenmiştir. Ülke gündeminde olası sistem değişikliğine yönelik yapılan olumsuz eleștirilerinin odak noktasında, Türkiye'nin hükümet geleneği dışında yeni bir sisteme hazır olmadı̆̆ı, bu sistemin ülke yönetiminde kolaylıkla despotizme yol açabileceği ve Demirel’in bu değişikliği kendi şahsı için istediği iddiaları yer almaktadır. ${ }^{17}$

14 Sait Yılmaz, "Başkanlık Sistemi; ABD, Türkiye’ye Örnek Olabilir mi?”, Yeni Türkiye Dergisi, 51 (2013), s.630. 15 Tosun ve Tosun, Türkiye’nin Siyasal, s.6.

16 Doğan Kılınç, “Türkiye’de Bitmeyen Tartışma: Hükümet Sistemi Üzerine Değerlendirmeler”, Gazi Üniversitesi Hukuk Fakültesi Dergisi, 20/1 (2016), s.467.

17 Selçuk Duman, “Türkiye İçin Başkanlık Sistemi Değerlendirmeleri”, Yeni Türkiye Dergisi, 51 (2013), s.645. 
Sistem değişikliğine yönelik yapılan olumsuz eleştirilere karşın ülkenin biran önce başkanlık sistemine geçmesi gerektiğini savunan belli bir kesimde mevcuttur. Başkanlık sistemini konusunun Türkiye gündeminde yer almasını sağlayan, 1990’lı yıllarda Turgut Özal’ın isteği üzerine başkanlık sistemine ilişkin bir rapor hazırlayan Halil Şıvgın, nostaljik bir bakış açısıyla;

Başkanlık Sistemi bizim milletimizin asırlardır oluşturduğu tarihi geleneklerine uygun bir sitem olduğu için bu sistemi öneriyoruz. Biz... Han, Hakan, Padişah geleneği içerisinde şekillenmiş bir milletiz. Cumhuriyet döneminde de bu geleneğe aykırı olmayan davranışlar sergiledik. Atatürk için "tek adam”, İnönü için "ikinci adam” ve "milli şef” ifadelerini kullandık... Türkiye’de güçlü bir yürütme isteyen siyasal bir hareketin Başkanlık modelinden yasa olması kaçınılmazdır.

Açıklamalarıyla sistem değişikliği aleyhinde fikirlerini yansıtmıştır. Şıvgın, yönetimde siyasi istikrarın sağlanamadığında aynı doğrultuda ekonomik istikrarında yakalanamadığını, böyle bir durumda da Türkiye’nin ileri gitmediğini, ekonomik ve siyasi istikrarın temin edilebilmesi için başkanlık sistemine geçilmesinin gerekliliğini vurgulamıştır ${ }^{18}$. Olası sistem değişikliği önerisi Hüsamettin Cindoruk ve Tansu Çiller gibi siyasetçiler tarafından da destek bulmuştur.

Süleyman Demirel'in görev süresinin tamamlanmasına az bir zaman kala iktidarda olan koalisyon hükümetinin meclise sunmuş olduğu anayasa değişikliği teklifiyle, "Cumhurbaşkanının görev süresini beş yıla indirip, bir kimsenin iki defa Cumhurbaşkanı seçilmesine” olanak veren bir taslak hazırlanmıştır. Ancak oylama sırasında yeterli çoğunluğa ulaşamadığı için bu öneri kabul edilmemiştir. Bunun yanında Fazilet Partisi ile Doğru Yol Partisi milletvekillerince hazırlanan başka bir teklifte, "Cumhurbaşkanının beş yıllık bir süre için doğrudan halk tarafından seçilmesi" meclise sunulmuştur. Önerinin TBMM Anayasa Komisyonu'nda reddedilmesiyle birlikte alternatif hükümet sistemi tartışmaları kısa süreliğine rafa kaldırılmıştır ${ }^{19}$.

\section{Recep Tayyip Erdoğan Dönemi}

Siyasi partilerin tek başına iktidar olabilecekleri gereken oy miktarına ulaşamamalar1 sonucu Türkiye uzun dönemler boyunca koalisyon hükümetleriyle yönetilmiştir. 1960'lardan 2000'lere kadar yaklaşık 22 yıl boyunca oluşturulan istikrarsız koalisyon hükümetleri, Türk siyasal yaşamına damgasını vurmuştur. 2002 genel seçimleriyle birlikte tek başına iktidara gelen AKP (Ak Parti) 59. Hükümet'in kurulmasının ardından alternatif hükümet sistemi tartışmaları arasındaki yerini almıştır.

59. Hükümet'in kurulmasından kısa bir süre sonra Başbakan Erdoğan, katılmış olduğu televizyon programında: "Başkanlık sistemi konusunda bir konsensüs sağlanırsa, Türkiye’nin ciddi bir sıçrama yapacă̆ına inanıyorum. Başkanlık ve yarı başkanlık sistemi siyasetteki arzumdur... Benim için ideali Amerikan Modelidir." şeklinde

18 Halil Şıvgın, Türkiye İçin Umut Krizden Çıkış Yeniden Yapılanma ve Başkanlık Sistemi, Ankara: Türk Dünyasında Demokrasiyi Geliștirme Vakfı Yayınları, 1997, s.10, 16.

19 Erdal Onar, “Türkiye’nin Başkanlık...”, s.85-86. 
ifadeleriyle hükümet sistemiyle ilgili görüşlerini belirtmiştir ${ }^{20}$. Erdoğan’ın televizyon programı aracılığıyla sistem değişikliğine ilişkin yapmış olduğu açılamaları, toplumun geniş kesimlerine ulaşarak ülke gündeminde büyük yankı uyandırmıştır.

Erdoğan’ın sisteme yönelik arzularının açıklamasının ardından dönemin Dışişleri Bakanı Abdullah Gül, başkanlık sisteminin AKP'nin kuruluş felsefesinde de bulunduğunu öne sürerek Erdoğan’ı destekleyen isimler arasında olmuştur. Bakan Gül, "Biz daha partiyi kurarken bunları tartıştık. Sayın Başbakan’ın söyledikleri doğru.” açıklamasında bulunmuştur. Ardından başkanlık sisteminin olanaklarından getirdiği avantajlardan söz ederek böyle bir köklü değişikliğin büyük bir uzlaşma alanına dayanarak yapılması gerekliliğinde altını çizmiştir ${ }^{21}$.

Hükümet sistemi değişikliğinin yeniden ülke gündemine girmesini önemsediğini belirten Başbakan Yardımcısı Mehmet Ali Şahin, "Türkiye için başlangıçta yarı başkanlık sistemi ile geçiş yapmak daha yararlı" olacağını ifade ederken; TBMM Başkanı Bülent Arınç, bu tartışmaların yeni olmadığını daha önceki dönemlerde de gündeme geldiğini belirterek, kamuoyunun bu konuyu tartışacağını ifade etmiştir. Arınç, "Anayasalar Meclis'te değiştiriliyor. Bundan sonra da değiştirilebilir. Şu anda oluşmuş bir konu da yok. Başbakan kendi düşüncelerini ifade etmiştir. Bu noktada herkesin saygı duyması gerekir.” olumlu eleştirisiyle sistem değişikliğine yeşil ışık yakmıştır. Diğer yandan Milli Savunma Bakanı Vecdi Gönül, Başbakan Erdoğan’ın ülke gerçeklerini en iyi şekilde belirlediğini ifade ederek, önerilen başkanlık sisteminin Ankara'nın ağır bürokrasi trafiğini azaltıp düzene sokacağını ve bunların tartışılmasını hedeflediğini belirtmiştir 22 .

Başbakan Erdoğan, olası sistem değişikliğinde arzuladığı modelin, Amerikan tipi başkanlık sistemi olduğunu belirtmesinin ardından onun bu görüşlerini destekleyenlerin yanı sıra çok farklı kesimlerden ve siyasi parti liderlerinden eleştirenlerde olmuştur.

CHP Genel Başkanı Deniz Baykal, Erdoğan tarafından yeniden canlandırılan başkanlık sistemi tartışmalarının ciddiyetten uzak olduğunu ifade ederek, AKP'nin sisteme yönelik Amerikan örneğine karşılık Arjantin örneğini göstermiştir. Baykal, "Eyalet sistemine mi geçeceksiniz, çift meclis mi açacaksınız? Ciddi şeyler değil bunlar. Önündeki meseleleri hallet, devleti niye şekillendiriyorsun. Herkes haddini bilsin." sözleriyle arzulanan sisteme bakış açısını sert bir şekilde ifade etmiştir ${ }^{23}$. ANAP eski milletvekilleri böyle bir sistemin kabulü söz konusu olduğunda, ülkede kolaylıkla diktatörlüğe yol açabileceğini ileri sürerken, ANAP Genel Başkanı Ali Talip Özdemir ise Erdoğan’ ülke gündemini değiştirmeye çalıştığını, kendisinin sistem değişikliği değil krallık istediğini iddia ederek sistemi olumsuz eleştiri getirenler arasında olmuştur ${ }^{24}$.

20 Milliyet, "Başkanlık İstiyor", 21 Nisan 2003, s.1.

21 Fikret Bila, “Erdoğan ve Gül' ün Yaklaşımları”, Milliyet, 21 Nisan 2003, s.16.

22 Hürriyet, Şahin’den başkanlık sistemine destek. 22 Nisan 2003. http://www.hurriyet.com.tr/sahindenbaskanlik-sistemine-destek-141935 (Erişim 12 Nisan 2017).

23 Milliyet, Baykal'dan Erdoğan’a Haddini Bil, 23 Nisan 2003, s.16.

24 Cumhuriyet, Erdoğan Krallık İstiyor, 24 Nisan 2004, s.4 
21 Aralık 2004 yılında Başbakanlık bütçesi görüşülürken parti adına konuşma yapan Kuzu, 82 Anayasası'nın başbakanın iktidar alanını güçlendirdiğini ancak Cumhurbaşkanı makamına parlamenter sistemle örtüşmeyecek yetkilerin verildiğini ileri sürmüştür. Ardından Anayasal düzende Cumhurbaşkanın sorumlu kılmadığı halde yetkili kıldığını belirterek bu yapıyı eleştirmiştir ${ }^{25}$. Ayrıca parlamenter sistemde yer alan başkanın, Amerikan Başkanı'na oranla iki kat daha yetkili olduğunun altını çizen Kuzu, bu sistemin Türk parlamenter yapısındaki hükümet sayısının fazlalığ 1 problemini ortadan kaldıracağını aynı zamanda milletvekillerinin aktif olarak siyasal hayatta rol alacaklarını öne sürmüştür ${ }^{26}$. Dönemin Cumhurbaşkanı Ahmet Necdet Sezer, yeni yıl (2005) mesajında başkanlık sisteminin yaratacağı tehlikelere değinerek şu noktalara dikkat çekmiştir;

Anayasada, demokratik devlet niteliği Türkiye Cumhuriyeti’nin değiştirilemez nitelikleri arasında sayılmış, demokrasiye en uygun olması nedeniyle de parlamenter hükümet sistemi kabul edilmiştir... Seçim yasalarındaki aksaklık nedeniyle yasama ve yürütmenin tek parti egemenliğine girmesi sonucunu doğuracak bir seçim sistemi, temsilde adalet ilkesiyle bağdaşmayacağ demokrasiye, giderek rejime büyük zarar verebilecektir ${ }^{27}$.

Özal, Demirel ve Erdoğan döneminde sistem tartışmalarına genel olarak bakıldığında üçünün de ortak paydası, ülke yönetimindeki ve ekonomideki istikrar başarısını elde etme amaçları olmuştur. Amerikan tipi başkanlık modelini açıkça arzuladığını belirten Ak Parti üyeleri istikrarın yanı sıra milletvekillerinin etkinliğini sağlamak adına hükümet sistemi değişikliğini ön gören tartışmaları başlatarak günümüze kadar taşımışlardır.

2006 yılından itibaren düşük yoğunlukta devam eden bu tartışmalar 2007 yılına gelindiğinde 11. Cumhurbaşkanının seçilme sürecinde yaşanan krizle birlikte mevcut hükümet sistemi değişikliği yeniden kamuoyunun gündemini meşgul etmeye başlamiştır.

Cumhurbaşkanı seçilebilmek için, Anayasa Mahkemesinin tanımlamış olduğu 102. madde uyarınca ilk "iki turda nitelikli çoğunluk (306 oy)" daha sonraki iki turda ise "salt çoğunluk (267 oy)" şartı aranmaktadır. Yargıtay Başsavcı Sabih Kanadoğlu'nun Cumhuriyet Gazetesi’nde yayınlamış olduğu Cumhurbaşkanın niteliklerini ve tarafsızlığını ele aldığı yazısında; Cumhurbaşkanın belirlenmesi kararında gerekenlerden biride "nitelikli çoğunluk katılımının aynı zamanda toplantı yeter sayısı" olduğunun altını çizmiştir.

Parlamentodaki ana muhalefet partisi ve diğer parti grubu üyeleri Cumhurbaşkanlığı seçimi oylamasına katılmayarak, Ak Parti iktidarının tek başına 11. Cumhurbaşkanının göreve getirmesine engel olmuşlardır. Kamuoyunda “367 Kararı” olarak anımsanan bu karara bir tepki olarak AKP erken genel seçimlere gitme teklifini

25 Duman, “Türkiye İçin Başkanlık”, s.160.

26 Bertil Emrah Oder, “Türkiye’de Başkanlık ve Yarı Başkanlık Rejimi Tartışmaları”, Teoman Ergül (der.),

Başkanlık Sistemi, Ankara: Türkiye Barolar Birliği Yayınları, 2005, s.61.

27 "Yeni Yll Mesajı", son güncelleme 10 Mayıs 2017, https://www.tccb.gov.tr/basin-aciklamalari-ahmet-necdetsezer/1720/6491/yeni-yil-mesaji.html . 
parlamentoya sunmuştur. Diğer parti üyelerinin de kabulüyle erken seçime gidilmesinin yanı sıra Cumhurbaşkanının halk tarafından seçilmesini ön gören anayasa değişikliği süreci de başlatılmıştır. 2007 yılında referandum ile kabul edilen anayasa değişikliği ile başkanlık rejimlerindeki temel niteliklerden birini oluşturan devlet başkanı makamının vatandaşlar tarafından seçilmesine karar kılınmıştır ${ }^{28}$.

Tarafsız bir kurum olan Cumhurbaşkanlığı makamının halk tarafından belirlenmesinin, Cumhurbaşkanını siyasallaştıracağını ileri süren Ahmet Necdet Sezer;

...Siyasal sistemle doğrudan ilgili olan bu değişikliğin anayasal sistemi tümüyle ele alıp gerekli düzenlemeler öngörmeden yapılması parlamenter rejimin özüyle bağdaşmayacak... Parlamenter sistem içinde iktidar gücünü dengelemek için öngörülen geniş yetkiler, halk tarafından seçilmiş bir Cumhurbaşkanının kullanımında çok farklı ve rejim yönünden sakıncalı sonuçlar doğurabilecektir... Cumhurbaşkanının seçimini sağlayan partiye olan gönül borcu nedeniyle yansız ve bağımsız davranamayacağı, ikinci kez seçilme olasılığının, Cumhurbaşkanını kimi siyasal partileri hoşnut etme, bir siyasal partiyle özellikle iktidarla özdeşleştirme yoluna itebileceğini, bu durumun da tarafsılı̆̆g zedeleyeceğini, istikrar ve denge sağlayıcı işlevini anlamsız kılacağı... ${ }^{29}$

Gerekçelerini sebep göstererek, kanunu onaylamayarak meclise iade etmiştir. Ardından ilgili kanunun değiştirilmeden TBMM geçirilmesi, Cumhurbaşkanına ikinci bir veto yetkisi tanınmaması durumunu oluşturduğu için halk oylaması kararı alınmıştir.

Kabul edilen Anayasa değişikliğiyle birlikte görev süresi beş yıla indirilen Cumhurbaşkanı, halk tarafından art arda iki dönem $(5+5)$ boyunca seçilebilecektir. Cumhurbaşkanı, TBMM üyeleri arasından çıkartılacağı gibi aynı zamanda 20 milletvekilinin yazılı teklifiyle birlikte parlamento dışından da aday gösterilebilecektir ${ }^{30}$.

11. Cumhurbaşkanının seçilme sürecinde yaşanan krizle birlikte hükümet sistemi değişikliği tartışmaları yeniden gündeme taşınmıştır. Halk oylamasına giden Anayasa paketi \%68.95 "Evet” oyuyla kabul edilmesi sonucu Cumhurbaşkanı makamı TBMM tarafından değil, doğrudan halk tarafından belirlenecektir. Dolayısıyla seçmenin iradesiyle belirlenmiş olan Cumhurbaşkanlığı makamı daha güçlendirilmiştir. Yaşanan bu değişim göz önüne alındığında ülkemizde bazı akademisyenler hükümet yönetiminin "yarı başkanlık rejimine dönüştüğünü” ileri sürmüşlerdir. Fakat sandık sonucu ülkemizdeki sistemi Amerikan tipi bir başkanlık modeli ya da 58 . Fransız Hükümeti'nin benimsemiş olduğu yarı başkanlık sistemlerini getirmemiştir. Biz demokratik parlamenter sistemden ayrılmadan yürütme erkinin biraz daha güç kazandırıldığını söyleyebiliriz.

28 Levent Gönenç, “Türkiyede Hükümet Sistemi Tartışmalarına Kısa Bir Bakış ve Mevcut Hükümet Sisteminin Niteliği”, Türkiye Ekonomi Politikaları Araştırma Vakfı, Nisan 2011, s.2.

29 “10.5.2007 Tarihli ve 5660 Sayılı T.C. Anayasasının Bazı Maddelerinde Değişiklik Yapılması Hakkında Kanun ve Anayasanın 89 uncu ve 104 üncü Maddeleri..., son güncelleme 10 Mayıs 2017, https://www.tbmm. gov.tr/sirasayi/donem22/yil01/ss1433m.htm

30 “Anayasa değişikliği paketi kabul edildi”, Sabah internet sitesi, 10 Mayıs 2007, http://arsiv.sabah.com. tr/2007/05/10/haber,BB63A2F0C5114812B85DF34520DA7C36.html (Erișim tarihi 10 Nisan 2017). 
Türkiye’de 2007 Anayasa değişikliği sonrasında ele alınan çoğu akademik çalışma, Shuggart ve Carey'in hükümet sistemlerini beş sınıfa ayırmasından hareketle, 2014 yılında Cumhurbaşkanlığı seçiminden sonraki dönemde Türkiye’nin; "Başbakanc1 Başkanlık Sistemi”, "Başkancı Parlamenter Sistem”, "Başkanlı Parlamenter Sistem” bu üç siyasal yapıdan birine yöneleceğini ileri sürmüştür.

Ak Partinin "2023 Siyasi Vizyonu” değerlendirildiğinde sistem değişikliğiyle ilgili ortaya atılan iddiaların destekler nitelikte olduğu görülmüştür.

Cumhurbaşkanını halkın seçmesini öngören referandum kararından sonra, Türkiye'de siyasî sistem değişikliği bir zorunluluk halini almıştır... Partili cumhurbaşkanı, yarı-başkanlık veya başkanlık sistemleri bu çerçevede tartışılmalıdır... Halkın iradesinin yönetime daha etkin yansıdığı; yürütmenin yasama tarafından etkin denetlenebildiği; istikrarlı, etkin, güçlü ve tek başlı bir yürütmenin olduğu; krizlerin ve her tür sorunun çözümü için daha cesur ve hızlı kararlar alınabildiği; halka hesap verme ve halkın hesap sorması bakımından açıklık ve şeffaflığın bulunduğu bir sisteme geçilmesi zaruridir. AK Parti, Türkiye’nin siyasi sisteminde yapısal bir sorun olduğunu düşünmekte, buna yapısal bir çözüm bulmak gerekliliğine inanmaktadır. Onun için başkanlık, yarı-başkanlık veya partili cumhurbaşkanlığı tercihlerinden birinin seçilip uygulanması şarttır ${ }^{31}$.

Anayasamızda geniş çaplı reform arayışları uzun yıllar Türkiye’nin gündemini meşgul etmiştir. 12 Haziran 2011 seçimleriyle birlikte bu çalışmalarda soyut adımlar atılmaya başlanmıştır. Ak Parti grubu üyeleri Kasım 2012'ye gelindiğinde yeni anayasa önerisini Anayasa Uzlaşma Komisyonu'na sunmuştur ${ }^{32}$. Sunulan öneride, başta yarg1 alanı olmak üzere diğer birçok kurum ve kuruluşlarda yeni düzenlemeler getirmekle birlikte, yeni hükümet yönetim sistemi olarakta "başkanlık sistemi” öngörülmektedir. Ardından Ak Parti’nin 7 Haziran 2015 genel seçimlerinde, içinde ekonomik kalkınma, istikrar, nitelikli toplum konularının bulunduğu bir seçim beyannamesi yayınlamıştır" tiyaç duyduğu etkin ve dinamik yönetim dolayısıyla, başkanlık sisteminin daha uygun bir yönetim modeli olduğuna inanıyoruz." maddelerin kamuoyuyla paylaşılmasının ardından tartışmalar başkanlık sistemi üzerine yoğunlaşmıştır.

Uzun süren çalışmaların ardından 2016 yılında AK Parti ve MHP ile yürütülen müzakerelerin ardından "başkanlık modeli” esasına dayanan "Anayasa Değişikliği Teklifi” hazırlanmıştır. AKP ve MHP arasında sağlanan mutabakat sonucu 10 Aralık 2016'da TBMM’ye sunulan, 82 Anayasası'nın yaklaşık 70 maddesini değiştiren teklif, 20 Ocak’ta TBMM'de kabul edilmiştir ${ }^{34}$. Siyasetçilerin, 12 maddesinin sistem deği-

31 “2023 Siyasi Vizyon”, son güncelleme 10 Mayıs 2017, http://www.akparti.org.tr/site/akparti/2023-siyasivizyon\#bolum_.

32 “Anayasa Uzlaşma Komisyonu Çalışmalarına İlişkin Sonuç Dokümanları”, son güncelleme 10 Mayıs 2017, https://anayasa.tbmm.gov.tr/calismalara_iliskin_belgeler.aspx.

33 “7 Haziran 2015 tarihli seçim beyannamesi”, son güncelleme 10 Mayıs 2017, www.akparti.org.tr/upload/ documents/2015-secim-beyannamesi-20nisan.pdf.

34 Mert Hüseyin Akgün, "Başkanlıktan Cumhurbaşkanlığı Sistemine: 2012 ve 2016 Ak Parti Anayasa Önerileri”, 
şikliğii, dokuz maddesinin ise yürütmeye ilişkin sunmuş oldukları anayasa değişikliği teklifi Cumhurbaşkanı Recep Tayyip Erdoğan’ın onaylamasının ardından halk oylamasına sunulmuştur.

\section{Başkanlık Sistemi Tartışmalarının Ulusal Yazılı Basına Yansımaları}

Araştırmamızın sınırlılıkları göz önünde bulundurularak gazeteler taranmış ve elde edilen değerler tablolara aktarılmıştır. Çalışmamıza başlamadan önce ilk olarak 1 Eylül 2016 tarihinden itibaren Hürriyet, Sabah ve Sözcü gazetelerinin ilk sayfaları ayrıntılı bir şekilde taranmış olup herhangi bir sistem değişikliği haberine rastlanılmadığı belirlenmiştir.

Tablo 1. Gazetelerin İlk Sayfalarında Yer Verilen Haber Sayısı

\begin{tabular}{|l|c|c|}
\hline Gazeteler & Haber Sayısı & Oran \\
\hline Hürriyet & 24 & 31 \\
\hline Sabah & 35 & 44 \\
\hline Sözcü & 20 & 25 \\
\hline Toplam & 79 & 100 \\
\hline
\end{tabular}

11 Ekim 2016 ile 10 Aralık 2016 tarihleri arasında 61 günü kapsayan bir süre zarfında Hürriyet, Sabah ve Sözcü gazetelerinin vitrin sayfaları olarak nitelendirdiğimiz ilk sayfalarında "başkanlık sistemi ve anayasa değişikliğiyle" ilgili toplamda 79 adet habere yer verilmiştir. Tablo l'e bakıldığında 35 adet haberle \%44'lük bir orana ulaşan Sabah gazetesi araştırmaya konu olan süre kısıtlamasında toplamda en çok haber yapan medya kuruluşu olarak görülmektedir. Hürriyet Gazetesi konuyla ilgili yer verdiği 24 haberiyle \%31'lik bir oranla Sabah Gazetesi'ni takip etmektedir. Haber sayısının Hürriyet Gazetesi'ne biraz yakın olan fakat konuyu en az haberleştiren yayın kuruluşu ise 20 haber ile \%25’lik bir orana sahip olan Sözcü Gazetesi olmuştur.

Tablo 2. Aylara Göre Başkanlık Tartışmalarının Gazetelerdeki Haber Sayısı

\begin{tabular}{|l|c|c|c|c|c|c|c|c|}
\hline & \multicolumn{2}{|c|}{ Hürriyet } & \multicolumn{2}{c|}{ Sabah } & \multicolumn{2}{c|}{ Sözcü } & \multicolumn{2}{c|}{ Toplam } \\
\hline & Sayı & Oran & Sayı & Oran & Sayı & Oran & Sayı & Oran \\
\hline 11-31 Ekim & 10 & 42 & 17 & 49 & 10 & 50 & 37 & 47 \\
\hline 1-30 Kasım & 9 & 37 & 13 & 37 & 8 & 40 & 30 & 38 \\
\hline 1- 10 Aralı & 5 & 21 & 5 & 14 & 2 & 10 & 12 & 15 \\
\hline Toplam & 24 & 100 & 35 & 100 & 20 & 100 & 79 & 100 \\
\hline
\end{tabular}

Araştırmaya konu olan olayın haberleştirilmesinde üç ulusal gazetenin haberi ele alış sayısı ay bazında Tablo 2'de değerlendirilmiştir. Hürriyet Gazetesi 11-31 Ekim tarihleri arasında 10 haberle \%42'lik, 1-30 Kasım arası 9 haber ile \%37'lik son olarak 1-10 Aralık tarihleri arasında 5 haberle \%21'lik bir oranda konuyu ilk sayfalarına taşıdığı görülmektedir. Bunun yanı sıra Hürriyet Gazetesi vitrin sayfalarında baş-

https://setav.org/assets/uploads/2017/01/Perspektif163.pdf (erişim 10.05.2017). 
kanlık sistemiyle ilgili toplamda 4 adet karikatüre yer verilmiştir. Fakat araştırmanın sınırlılığı kapsamında sadece gazete yazı türü olarak haber metinleri incelendiği için karikatürler analiz dişında tutulmuştur. Sabah yayın kuruluşu 11-31 Ekim tarihleri arasında 17 haberle \%49'luk, 1-30 Kasım aralığında 13 haberle \%37'lik son olarak 1-10 Aralık tarihleri arasında 5 haber ile olayı ilk sayfalarında ele aldığı görülmektedir. Sözcü Gazetesi başkanlık sistemiyle ilgili söylemleri en az haberleştiren yayın kuruluşu olmakla birlikte 11-31 Ekim tarihleri arasında 10 haberle \%50'lik, 1-30 Kasım arasında 8 haberle \%40 son olarak 1-10 Aralık süresi boyunca 2 haberle \%10'luk bir oranda tartışmaları ele almıştır.

Genel olarak değerlendirildiğinde haber aktörü olarak siyasi liderin yapmış olduğu açılamanın hemen ardından 11-31 Ekim tarihleri arasında üç gazetenin 37 haber \%47'lik bir oranla en fazla haber sayısına ulaşarak medya gündeminin başkanlık sistemi tartışmaları yönünde belirlendiği görülmektedir. 1-30 Kasım tarihleri arasında bir önceki aydan az olmakla beraber 30 haberle \%38'lik bir oranla gündemde kaldığı, 1- 10 Aralık tarihlerine gelindiğinde ise yavaş yavaş medya gündeminde ilgili konunun öneminin kaybedildiği belirlenmiştir.

Tablo 3. Gazete Haber Metinlerinin Vitrin Sayfalardaki Konumu

\begin{tabular}{|l|c|c|c|c|c|c|c|c|}
\hline & \multicolumn{2}{|c|}{ Hürriyet } & \multicolumn{2}{c|}{ Sabah } & \multicolumn{2}{c|}{ Sözciu } & \multicolumn{2}{c|}{ Toplam } \\
\hline & Sayı & Oran & Sayı & Oran & Sayı & Oran & Sayı & Oran \\
\hline Sürmanşet & 0 & 0 & 0 & 0 & 0 & 0 & 0 & 0 \\
\hline Manşet & 5 & 21 & 10 & 29 & 6 & 30 & 21 & 21 \\
\hline Üst Kuşak & 0 & 0 & 0 & 0 & 2 & 10 & 2 & 3 \\
\hline Katlama Çizgisi & 4 & 17 & 1 & 3 & 4 & 20 & 9 & 11 \\
\hline Alt Kuşak & 10 & 41 & 18 & 51 & 7 & 35 & 35 & 44 \\
\hline Ayak & 5 & 21 & 6 & 17 & 1 & 5 & 12 & 15 \\
\hline Toplam & 24 & 100 & 35 & 100 & 20 & 100 & 79 & 100 \\
\hline
\end{tabular}

Tablo 3'e üç ulusal gazetenin konuyla ilgili haberleri ilk sayfalarında nasıl yer verildiğinin analizi aktarılmıştır. Hürriyet Gazetesi’nin 61 günlük süre zarfında konuyu yalnızca 5 adet \%21'lik bir oranla manşetine taşıdığ 1 görülmektedir. Gazete, katlama çizgisi olarak belirlenmiş olan yerde 4 adet \%17'lik oranda, gazetenin ayak kısmı olarak nitelendirilen yerde ise 5 adet \%21'lik bir oranda haberleri ilk sayfasına taş1mıştır. Hürriyetin en fazla konuyu ele aldığg yer 10 haber, \%41'lik bir oranla alt kuşak olduğu görülmektedir. Sabah Gazetesi 10 haber, \%29'luk bir oranla diğer ulusal gazetelere göre ilgili konuyu manşetine en fazla taşıyan yayın gurubu olmuştur. Katlama çizgisinde yalnızca 1 habere yer veren gazete, konuyla alakalı 6 haberini \%17'lik bir oranda ayak kısmında konumlandırmıştır. Sabah Gazetesi’nin diğer gazetelere karşın konuyu sayfaya en fazla taşıdığı yer 18 haber ile \%51'lik bir oranla alt kuşak olmuştur. Sözcü Gazetesi, konuyla ilgili haberleri sayfasına taşırken; manşetine 6 haber ile \%30’luk, üst kuşağına 2 haberle \%10’luk, katlama çizgisine 4 haberle \%20'lik bir oranda yer ayırmıştır. Gazete, manşet haber sayısından bir sayı fazla olarak 7 ha- 
ber, \%35'lik bir oranda sayfa tasarımını gerçekleştirmiştir. Hürriyet, Sabah ve Sözcü gazeteleri toplamda 35 haber, \%44'lük bir oranla en fazla haberlerini gazetenin alt kuşak olarak nitelendirilen kısmında konumlandırmıştır. Bu sayıyı 21 haber, \%21'lik bir oranla gazetelerin manşetleri takip ettiği görülmektedir.

Tablo 4. Haber Metinlerinde Kullanılan Görsel Öge Türleri

\begin{tabular}{|l|c|c|c|c|c|c|c|c|}
\hline & \multicolumn{2}{|c|}{ Hürriyet } & \multicolumn{2}{c|}{ Sabah } & \multicolumn{2}{c|}{ Sözcü } & \multicolumn{2}{c|}{ Toplam } \\
\hline & Sayı & Oran & Sayı & Oran & Sayı & Oran & Sayı & Oran \\
\hline Fotoğraf & 22 & 92 & 35 & 100 & 16 & 80 & 73 & 92 \\
\hline Fotoğrafsız & 1 & 4 & - & - & 1 & 15 & 2 & 3 \\
\hline Karikatür & 1 & 4 & - & - & 3 & 5 & 4 & 5 \\
\hline Diğer & - & - & - & - & - & - & - & - \\
\hline Toplam & 24 & 100 & 35 & 100 & 20 & 100 & 79 & 100 \\
\hline
\end{tabular}

Başkanlık sistemi ve anayasa değişikliğiyle ilgili haberlerin ilk sayfalardaki sunumlarında toplamda her üç gazete \%92'lik bir oranla görsel öge olarak fotoğrafı tercih ettiği görülmektedir. Sabah Gazetesi, grafik ve karikatürlere hiç yer vermezken Hürriyet Gazetesi \%4, Sözcü Gazetesi’nin ise \%5'lik bir orada haber metinlerinde karikatür kullanıldığı belirlenmiştir.

Tablo 5. Görsel Öğelerin Sayfa İçinde Konumlandırılması

\begin{tabular}{|l|c|c|c|c|c|c|c|c|}
\hline & \multicolumn{2}{|c|}{ Hürriyet } & \multicolumn{2}{c|}{ Sabah } & \multicolumn{2}{c|}{ Sözcü } & \multicolumn{2}{c|}{ Toplam } \\
\hline & Sayı & Oran & Sayı & Oran & Sayı & Oran & Sayı & Oran \\
\hline Sürmanşet & 0 & 0 & 0 & 0 & 0 & 0 & 0 & 0 \\
\hline Manşet & 5 & 21 & 10 & 29 & 6 & 30 & 21 & 21 \\
\hline Üst Kuşak & 0 & 0 & 0 & 0 & 2 & 10 & 2 & 3 \\
\hline Katlama Çizgisi & 4 & 17 & 1 & 3 & 4 & 20 & 9 & 11 \\
\hline Alt Kuşak & 10 & 41 & 18 & 51 & 7 & 35 & 35 & 44 \\
\hline Ayak & 5 & 21 & 6 & 17 & 1 & 5 & 12 & 15 \\
\hline Toplam & 24 & 100 & 35 & 100 & 20 & 100 & 79 & 100 \\
\hline
\end{tabular}

Elde edilen verilere göre Hürriyet Gazetesi, \%41'lik bir oranla 10 haber görselini en fazla alt kuşakta yer vermiştir. Manşette ve gazetenin ayak kısmı olarak nitelendirilen yerde \%21'lik bir oranda, gazetenin katlama çizgisinde ise \%17'lik bir oranda haber görselleri konumlandırılmıştır. Benzer bir şekilde Sabah Gazetesi, \%51'lik bir oranla en fazla haber görselini alt kuşakta kullanmıştır. Ardından manşette 10, ayakta 6, katlama çizgisinde ise yalnızca 1 haber görseline yer ayırmıştır. Diğer gazetelerden farklı olarak Sözcü Gazetesi, toplamda 3 karikatüre manşet, katlama çizgisi ve alt kuşakta yer vermiştir. Alt kuşakta 7, manşette 6 haber görseli kullanan Sözcü Gazetesi, ayak kısmında yalnızca 1 haber görseline yer vermiştir. Gazetelerin tüm sayfalarında kullanılan görsel öğelerin renkli olduğu belirlenmiştir. 
Tablo 6. Haber Görsellerinde Yer Verilen Siyasi Aktörler

\begin{tabular}{|l|c|c|c|c|c|c|c|c|}
\hline & \multicolumn{2}{|c|}{ Hürriyet } & \multicolumn{2}{c|}{ Sabah } & \multicolumn{2}{c|}{ Sözcü } & \multicolumn{2}{c|}{ Toplam } \\
\hline & Sayı & Oran & Sayı & Oran & Sayı & Oran & Sayı & Oran \\
\hline Recep Tayyip Erdoğan & 2 & 6 & 6 & 14 & 4 & 14 & 12 & 11 \\
\hline Binali Yıldırım & 11 & 34 & 21 & 49 & 8 & 27 & 40 & 38 \\
\hline Devlet Bahçeli & 12 & 38 & 9 & 21 & 8 & 28 & 29 & 28 \\
\hline Kemal Kılıçdaroğlu & 5 & 16 & - & - & 6 & 21 & 11 & 11 \\
\hline Bakanlar & - & - & 7 & 16 & 1 & 3 & 8 & 8 \\
\hline Diğer & 2 & 6 & - & - & 2 & 7 & 4 & 4 \\
\hline Toplam & 32 & 100 & 43 & 100 & 29 & 100 & 104 & 100 \\
\hline
\end{tabular}

Hürriyet Gazetesi, 61 günlük süre zarfında \%38'lik bir oranla haber görsellerinde en fazla Devlet Bahçeli'ye yer vermiştir. Ardından \%34'lük bir farkla Başbakan Binali Yıldırım, \%16 oranla Kemal Kılıçdaroğlu ve \%6'lık bir oranla da Cumhurbaşkanı Erdoğana yer vermiştir. Sabah Gazetesi $\% 49$ oranında Başbakan Yıldırıma yer verirken, \%21 Bahçeli’nin, \%16 bakanların, \%14 ise Cumhurbaşkanı Erdoğan’n fotoğraflarını vitrin sayfalarında ilgili haberlere taşıdığı görülmektedir. Gazete, haber görsellerinde Kemal Kılıçdaroğlu’na hiç yer vermemiştir. Devlet Bahçelìye ve Başbakan Yildırım’a eşit sayıda yer veren Sözcü Gazetesi, \%21'lik bir oranla Kemal Kilıçdaroğlu’na, \%4 Cumhurbaşkanı Erdoğan’a ve \%7'lik bir oranla ise diğer kişilere haber görsellerinde yer ayırdığı rastlanmıştır.

Tablo 7. Haberde Kullanilan Fotoğrafların Haber Metni ile İlişkisi

\begin{tabular}{|l|c|c|c|c|c|c|c|c|}
\hline & \multicolumn{2}{|c|}{ Hürriyet } & \multicolumn{2}{|c|}{ Sabah } & \multicolumn{2}{c|}{ Sözcï } & \multicolumn{2}{c|}{ Toplam } \\
\hline & Sayı & Oran & Sayı & Oran & Sayı & Oran & Sayı & Oran \\
\hline Uyumlu & 17 & 74 & 28 & 80 & 15 & 79 & 60 & 78 \\
\hline Uyumsuz & 3 & 13 & 5 & 14 & 4 & 21 & 12 & 16 \\
\hline Kısmen Uyumlu & 3 & 13 & 2 & 6 & - & - & 5 & 6 \\
\hline Toplam & 23 & 100 & 35 & 100 & 19 & 100 & 77 & 100 \\
\hline
\end{tabular}

Her üç gazetenin ilk sayfalarında kullanmış olduğu fotoğraflar ile haber metinleri arasındaki ilişki; "uyumlu", "uyumsuz" ve "kısmen uyumlu" değişkenleri altında incelenmiştir. Elde edilen verilerde Hürriyet Gazetesi \%74, Sabah \%80, Sözcü ise $\% 79$ 'luk birbirlerine yakın oranlarda fotoğraf ve metin arasındaki uyumluluğun sağlandığı belirlenmiştir. Hürriyet'in kullanmış olduğu 3, Sabahı̉n 5, Sözcünün 4 haber görselinde haber metinleri arasında uyumsuzluğun bulunduğuna rastlanılmıştır.

Tablo 8. Fotoğraf Altyazısının İçeriksel Özelliği

\begin{tabular}{|l|c|c|c|c|c|l|c|c|}
\hline & \multicolumn{2}{|c|}{ Hürriyet } & \multicolumn{2}{c|}{ Sabah } & \multicolumn{2}{c|}{ Sözcï } & \multicolumn{2}{c|}{ Toplam } \\
\hline & Sayı & Oran & Sayı & Oran & Sayı & Oran & Sayı & Oran \\
\hline Nesnel & 13 & 100 & 16 & 70 & 8 & 67 & 37 & 77 \\
\hline Nesnel Değil & - & - & 3 & 13 & 4 & 33 & 7 & 15 \\
\hline
\end{tabular}




\begin{tabular}{|l|c|c|c|c|c|l|c|c|}
\hline Kismen Nesnel & - & - & 4 & 17 & - & - & 4 & 8 \\
\hline Toplam & 13 & 100 & 23 & 100 & 12 & 100 & 48 & 100 \\
\hline
\end{tabular}

Hürriyet Gazetesi'nin araştırmaya dâhil haberlerinde toplamda 13 tane kullanılan fotoğraf altyazısının tamamında $\% 100$ oranında bir nesnelliğe sahip olduğu belirlenmiştir. Sabah Gazetesi, 16 fotoğraf altyazısında nesnel davranırken, geriye kalan 3 altyazıda nesnellikten uzaklaştığı, 4 fotoğraf altyazısında ise kısmen nesnel davrandığ 1 görülmüştür. Sözcü Gazetesi ise 8 fotoğraf altyazısında \%67'lik bir oranda nesnel, 4 fotoğraf altyazısında \%33'lük bir oranda nesnellikten uzaklaştığı rastlanılmıştır.

Tablo 9. Gazete Haberlerinin Oluşumundaki Olay

\begin{tabular}{|l|c|c|c|c|c|c|c|c|}
\hline & \multicolumn{2}{|c|}{ Hürriyet } & \multicolumn{2}{c|}{ Sabah } & \multicolumn{2}{c|}{ Sözcü } & \multicolumn{2}{c|}{ Toplam } \\
\hline & Sayı & Oran & Sayı & Oran & Sayı & Oran & Sayı & Oran \\
\hline Açılama & 9 & 38 & 6 & 17 & 4 & 20 & 19 & 24 \\
\hline Açılış & - & - & 6 & 17 & - & - & 6 & 8 \\
\hline Basın Toplantısı & - & - & 1 & 3 & - & - & 1 & 1 \\
\hline Grup Toplantısı & 4 & 17 & 4 & 11 & 3 & 15 & 11 & 14 \\
\hline Toplantı & 2 & 8 & 9 & 26 & 2 & 10 & 13 & 17 \\
\hline Miting & - & - & - & - & 1 & 5 & 1 & 1 \\
\hline Röportaj & 1 & 4 & 1 & 3 & 1 & 5 & 3 & 4 \\
\hline Ziyaret & - & - & - & - & 1 & 5 & 1 & 1 \\
\hline Diğer & 8 & 33 & 8 & 23 & 8 & 40 & 24 & 30 \\
\hline Toplam & 24 & 100 & 35 & 100 & 20 & 100 & 79 & 100 \\
\hline
\end{tabular}

Başkanlık sistemi ve anayasa değişikliğiyle ilgili haberlerin oluşumuna neden olan olaylar dokuz madde altında sıralanmıştır. İlk sekiz başlığın haricindeki olaylar "diğer” değişkeninde toplanmıştır. Hürriyet Gazetesi, ilgili konuyla ilgili en fazla haberleştirmeyi haber kaynaklarının açıklamaları üzerinden gerçekleştirmiştir. Parti üyelerinin grup toplantılarında yapmış olduğu konuşmalardan \%17 oranında 4 haber oluştururken, 1 haberini röportajdan oluşturmuştur. Gazetenin geriye kalan 8 haberini ise çeşitli olayların vesilesiyle oluşturduğu belirlenmiştir. Sabah Gazetesi, Hürriyet’ten farklı olarak 6 haberini liderlerin açılış törenlerindeki demeçlerden yola çıkarak oluşturmuştur. Gazete, 9 haberini \%26’lık bir oranla çeşitli nedenlerle gerçekleștirilen toplantılardan, 6 haberini açıklamalardan, 4 haberini \%17'lik bir oranla partilerin grup toplantılarından, 1 haberini basın toplantısından, 1 haberini röportajdan ve geriye kalan 8 haberini "diğer" değişkenine tanımladığımız olaylardan oluşturmuştur. Sözcü Gazetesi’nin tıpkı Hürriyet Gazetesi’nde olduğu gibi “açılışlar" kategorisinden ilgili konuları habere taşımaması dikkat çeken bir husus olmuştur. Gazete \%40 oranına sahip olan en fazla haberini "diğer" olayların vesilesiyle haberleştirmiştir. 
Tablo 10. Hürriyet Gazetesindeki Haber Metinlerinin İçerik Konuları

\begin{tabular}{|l|c|c|}
\hline İçerik Konuları & Sayı & Oran \\
\hline Anayasa Değişikliği & 4 & 17 \\
\hline Anayasa Teklifi & 1 & 4 \\
\hline Başkanlık Gelmezse & 1 & 4 \\
\hline Başkanlık Tartışması & 3 & 13 \\
\hline Dikta Rejimi & 1 & 4 \\
\hline Güçlendirilmiş Parlamenter Sistem & 3 & 13 \\
\hline MHP Evet mi Kullanacak & 1 & 4 \\
\hline Milletin Kararı & 2 & 9 \\
\hline Partili Cumhurbaşkanlığı & 2 & 8 \\
\hline Referandum & 2 & 8 \\
\hline Tek Derdi Koltuk & 2 & 8 \\
\hline Türkiye'yi Böldürmeyeceğiz & 1 & 4 \\
\hline Yeni Türkiye & 1 & 4 \\
\hline Toplam & 24 & 100 \\
\hline
\end{tabular}

Tablo 10'da Hürriyet Gazetesi'nin 61 günlük süre zarfında ilk sayfasına taşıdığı haber metinlerinin konu içeriği irdelenmiştir. Bu kapsamda gazete 4 haberinde \%17'lik bir oranla en fazla "Anayasa Değişikliği”" konusuna yer vermiştir. Ardından \%13'lük bir dilimi kapsayan “Güçlendirilmiş Parlamenter Sistem” ve "Başkanlık Tartışması”, \%9 oranında "Milletin Kararı", \%8'lik oranlarda "Partili Cumhurbaşkanlığı”, "Referandum" ve "Tek Derdi Koltuk" konularına haberlerinde yer verirken; "Anayasa Teklifi”, "Başkanlık Gelmezse”, "Dikta Rejimi”, "MHP Evet mi Kullanacak”, “Türkiye’yi Böldürmeyeceğiz" ve "Yeni Türkiye” şeklinde özetlendirilmiş olan kategorileri birer kez haber konusu olarak gazetede yer vermiştir.

Hürriyet Gazetesi’nin haber içeriklerinde; “Başbakan Binali Yıldırım’ın Anayasa açıklamasının ardından dolar, dün 3.0973 lira ile tarihi zirvesini gördü”, "AKP başkanlık sistemini referanduma götürebilmesi için parlamentoda kendi grubunun dişında en az 14 oya ihtiyacı var.” ifadeleri değindiği önemli noktalar olmuştur. Gazete haberinde, Bahçeli’nin başkanlık sisteminin fitilini ateşlikten sonra suskunluğunu koruduğunu, MHP kurmaylarının da Bahçeli’nin açıklamasına destek vermek ile ilgili elini açmadıklarını belirtmiştir. "Başkanlık gelmezse bölünme riski var" adlı haber başlığında Başbakan Binali Yıldırım’ın başkanlık sistemiyle ilgili yaptığ 1 açıklamaları "çarpııı ifadeler" şeklinde nitelendirerek federal yapı konusuna dikkat çekilmiştir.

Anayasa değişikliğinde bugüne kadar gündeme gelmemiş tekliflerin yer aldığını belirten haber içeriklerinde sık sık "MHP’nin desteği, isteği, iş birliği” şekilde ifadelere yer verilmiştir. Mevcut Anayasanın 70'e yakın maddesinde değişiklik yapıldı̆̆ını, MHP isteği üzerine Cumhurbaşkanın yetkilerini 2019'a kadar kullanamayacağının yer aldığı haber içeriklerinde TBMM'ye sunulan teklifteki bazı konuları "kritik" olarak nitelendirmiştir. 
Tablo 11. Sabah Gazetesindeki Haber Metinlerinin İçerik Konuları

\begin{tabular}{|l|c|c|}
\hline İçerik Konuları & Sayı & Oran \\
\hline Anayasa Değişikliği & 9 & 26 \\
\hline Darbeleri Önler & 1 & 3 \\
\hline Gazi Meclis & 2 & 5 \\
\hline İstikrar İçin Başkanlık & 1 & 3 \\
\hline Köklü Reform & 2 & 5 \\
\hline Millet Başkanlık diyor & 1 & 3 \\
\hline Milletin Kararı & 6 & 17 \\
\hline Partili Cumhurbaşkanlığı & 2 & 6 \\
\hline Referandum & 1 & 3 \\
\hline Sistem Değişikliği & 2 & 6 \\
\hline Tam Başkanlık & 2 & 6 \\
\hline Ülkenin Bekası & 3 & 8 \\
\hline Vesayet Anayasası & 2 & 6 \\
\hline Yeni Türkiye & 1 & 3 \\
\hline Toplam & 35 & 100 \\
\hline
\end{tabular}

Sabah Gazetesi'nin haber metinlerinde en fazla yer verdiği konu, \%26 oranında "Anayasa Değişikliğì" ile ilgili olduğu tespit edilmiştir. Bu sayıyı 6 haberle "Milletin Kararı" konularını içeren metinler takip etmektedir. Gazetede, "Ülkenin Bekası" 3 kere habere konu olurken, "Gazi Meclis”, "Köklü Reform”, "Partili Cumhurbaşkanlığı”, "Sistem Değişikliğì", “Tam Başkanlık”, "Vesayet Anayasası” gibi özet kategoriler ikişer kez haber metnine konu olduğu belirlenmiştir. \%3’lük dilimleri oluşturan "Darbeleri Önler", "İstikrar İçin Başkanlık", "Millet Başkanlık Diyor", "Referandum" ve "Yeni Türkiye" başlıklarının birer kez haber metinlerine konu oluşturduğuna rastlanmiștır.

Sabah Gazetesi’nin, haber içeriklerinde sık sık "Başkanlık, Tam Başkanlık, Cumhurbaşkanlığı” sistemleri adı altında Anayasa değişikliğinin ayrıntılarına yer vererek, "milletin iradesi, milletin kararı, ülkenin bekası" noktalarına dikkat çektiği belirlenmiştir. Yeni sistemin erkler arasında denge sağlayacağını, "AKP’nin Anayasa paketiyle özellikle yasama ve yürütme erkinin karşı karşıya gelme riskini” azalttığını haber içeriklerinde yer vererek "ne Başkan’ın Meclis'i ne de Meclis'in Başkan’a ezdirme tehlikesinin” kalmadığını belirtmiştir.

AKP’nin başkanlık sistemi isteğini bir strateji olarak değerlendiren gazete, haber içeriklerinde Başkanlık sisteminin gelince "şer odaklarının” biteceğini ileri sürmüştür. Bahçeli'nin sağduyusuyla oluşturulan birinin 17 maddeden diğerinin de 59 maddeden oluşan "kontrol dengeli Anayasa paketi ve Tam Başkanlık" önerildiğinin haber içeriklerinde belirtilen diğer bir unsur olmuştur. 
Tablo 12. Sözcü Gazetesi'ndeki Haber Metinlerinin Içerik Konuları

\begin{tabular}{|l|c|c|}
\hline İçerik Konuları & Sayı & Oran \\
\hline Anayasa Değişikliği & 2 & 10 \\
\hline Anayasa Pazarlığı & 1 & 5 \\
\hline Anayasayı Rafa Kaldırdı & 1 & 5 \\
\hline Demokrasi & 2 & 10 \\
\hline Elele Meclise & 1 & 5 \\
\hline Koltuk Derdi & 1 & 5 \\
\hline Meclisin Feshi & 1 & 5 \\
\hline OHAL döneminde Rejim Değiştirilmez & 1 & 5 \\
\hline Partili Cumhurbaşkanlığı & 2 & 10 \\
\hline Referandum & 1 & 5 \\
\hline Tek Adam & 4 & 20 \\
\hline Türk Tipi Başkanlık & 2 & 10 \\
\hline Türkiye’yi Böldürtmeyeceğiz & 1 & 5 \\
\hline Toplam & 20 & 100 \\
\hline
\end{tabular}

Sözcü Gazetesi’nin belirlenmiş süre kısıtlılığında araştırmaya dâhil olan olayla ilgili toplamda oluşturduğu 20 haberinden, 4 adedi \%20’lik bir oranla “Tek Adam” konusunu içermektedir. Gazetede, "Anayasa Değişikliği", "Demokrasi", "Partili Cumhurbaşkanlığı", "Türk Tipi Başkanlık” ikişer kez \%10 oranında haber konusunda dâhil edilirken; "Anayasa Pazarlığı”, "Anayasa Rafa Kaldırıldı", "Elele Meclise”, "Koltuk Derdi", "Meclisin Feshi”, "OHAL Döneminde Rejim Değiştirilmez", "Referandum" ve “Türkiye’yi Böldürtmeyeceğiz” başlıkları birer kez haber konusuna dâhil edildiği belirlenmiştir.

Sözcü Gazetesi’nin haber içeriklerinde, Cumhurbaşkanının yetkilerinin arttırıldığ1nın altını çizerek yeni Anayasa değişikliğinin maddelerine yer verildiği belirlenmiştir. Sistemin Tam başkanlık yönünde belirlenmesinin ardından gazetenin, “AKP’liler ağzındaki baklayı sonunda böyle çıkardı", "Ateş topu şimdi Devlet Bahçeli’nin kucağında" şeklinde ifadelere yer verdiği görülmektedir. "Yıllardır Türk tipi diyerek dayattıkları başkanlık modelini” bahane olarak nitelendiren Sözcü Gazetesi, "laikliği yeminden kaldırma” planlarının olduğunu, "milletvekilli yeminindeki Atatürk ilke inkılaplarına ve laik Cumhuriyet ilkesine bağlı kalacağıma” kısmının kaldırılma hazırlıklarının yapıldığını haber metinlerinde ileri sürmüştür. Başkanlığı bir anlaşma olarak nitelendiren gazetenin haber içeriğinde değindiği bir diğer nokta, bu anlaşmanın doları uçurduğu olmuştur.

Tablo 13. Hürriyet Gazetesinin Haber Konularında Siyasi Partilerin Ele Alınışı

\begin{tabular}{|l|c|c|c|c|c|c|c|c|}
\hline Hürriyet & \multicolumn{2}{|c|}{ AKP } & \multicolumn{2}{c|}{ MHP } & \multicolumn{2}{c|}{ CHP } & \multicolumn{2}{c|}{ HDP } \\
\hline & Sayı & Oran & Sayı & Oran & Sayı & Oran & Sayı & Oran \\
\hline Pozitif & 3 & 15 & - & - & 1 & 14 & - & - \\
\hline
\end{tabular}




\begin{tabular}{|l|c|c|c|c|c|c|c|c|}
\hline Negatif & 4 & 20 & 3 & 23 & - & - & - & - \\
\hline Nötr & 8 & 40 & 7 & 54 & 6 & 86 & 1 & 100 \\
\hline $\begin{array}{l}\text { Yukarıdakilerden } \\
\text { birkaçı }\end{array}$ & 5 & 25 & 3 & 23 & - & - & - & - \\
\hline Toplam & 20 & 100 & 13 & 100 & 7 & 100 & 1 & 100 \\
\hline
\end{tabular}

Tablo 13’te gazete haberlerindeki siyasi partilerin ele alınış biçimleri "pozitif”, "negatif”, "nötr", "yukarıdakilerden birkaçı” değişkenleri altında incelenmiştir. Bir haber metninde birden fazla haber aktörünün rol aldığı göz önünde bulundurularak Hürriyet Gazetesi haberlerinde, tüm partileri en fazla nötr olarak ele aldığı belirlenmiştir. Gazete haber konularında \%20 oranında AKP’yi, \%23 oranında MHP'yi negatif olarak sunarken; sırasıyla \%25'lik ve \%23'lük bir oranla “yukarıdakilerden birkaçı” değişkeninde tanımlanan konularla sunulduğu belirlenmiştir. İlgili haber metinlerinde CHP'nin \%86, HDP'nin ise tek haberle \%100 nötr olarak ele alındığ gözlemlenmiştir.

Tablo 14. Sabah Gazetesinin Haber Konularında Siyasi Partilerin Ele Alınışı

\begin{tabular}{|l|c|c|c|c|c|c|c|c|}
\hline Sabah & \multicolumn{2}{|c|}{ AKP } & \multicolumn{2}{c|}{ MHP } & \multicolumn{2}{c|}{ CHP } & \multicolumn{2}{c|}{ HDP } \\
\hline & Sayı & Oran & Sayı & Oran & Sayı & Oran & Sayı & Oran \\
\hline Pozitif & 16 & 70 & 11 & 69 & - & - & - & - \\
\hline Negatif & - & - & - & - & 4 & 100 & 3 & 100 \\
\hline Nötr & 6 & 26 & 3 & 19 & - & - & - & - \\
\hline $\begin{array}{l}\text { Yukarıdakilerden } \\
\text { birkaçı }\end{array}$ & 1 & 4 & 2 & 12 & - & - & - & - \\
\hline Toplam & 23 & 100 & 16 & 100 & 4 & 100 & 3 & 100 \\
\hline
\end{tabular}

Sabah Gazetesi'nde, AKP 16 haber konusuyla \%70 oranında pozitif, 6 haber ile \%26 oranında nötr ele alınırken, olayların içeriğinin negatif olarak yer verilmediği belirlenmiştir. Benzer bir şekilde MHP, 11 haberi \%69'luk bir oranla pozitif, 3 haberiyle \%19'luk bir dilimle nötr olarak yer verilirken, olayların içeriği negatif olarak sunulmamıștır. Gazete ilk sayfalarında CHP ve HDP’nin habere konu olan olaylarını ele alırken, \%100 oranında negatif olarak değerlendirdiği gözlemlenmiştir.

Tablo 15. Sözcü Gazetesinin Haber Konularında Siyasi Partilerin Ele Alınışı

\begin{tabular}{|l|c|c|c|c|c|c|c|c|}
\hline Sözcü & \multicolumn{2}{|c|}{ AKP } & \multicolumn{2}{c|}{ MHP } & \multicolumn{2}{c|}{ CHP } & \multicolumn{2}{c|}{ HDP } \\
\hline & Sayı & Oran & Sayı & Oran & Sayı & Oran & Sayı & Oran \\
\hline Pozitif & - & - & 1 & 7 & 6 & 67 & - & - \\
\hline Negatif & 12 & 92 & 9 & 60 & - & - & - & - \\
\hline Nötr & 1 & 8 & 3 & 20 & 3 & 33 & - & - \\
\hline $\begin{array}{l}\text { Yukarıdakilerden } \\
\text { birkaçı }\end{array}$ & - & - & 2 & 13 & - & - & - & - \\
\hline Toplam & 13 & 100 & 15 & 100 & 9 & 100 & - & - \\
\hline
\end{tabular}

Sözcü Gazetesi’nin, AKP ile ilgili 12 haberinde \%92 oranında, MHP ile ilgili 9 haberinde \%60’lık bir oranla olayların içeriği negatif olarak ele aldığg belirlenmiştir. Ga- 
zetenin, MHP ve CHP ile ilgili 3 haberinde, AKP ile ilgili 1 haberinde nötr yaklaştığ 1 gözlemlenmiştir. Sözcü Gazetesi, CHP ile ilgili olayların ele alınışında \%67’lik bir oranla pozitif davranırken, araştırmaya dâhil olan konuyla ilgili HDP’nin haberlerine hiç yer vermediği belirlenmiştir.

Tablo 16. Gazetelerde Haber Kaynağının Kullanımı

\begin{tabular}{|l|c|c|c|c|c|c|c|c|}
\hline & \multicolumn{2}{|c|}{ Hürriyet } & \multicolumn{2}{c|}{ Sabah } & \multicolumn{2}{c|}{ Sözcï } & \multicolumn{2}{c|}{ Toplam } \\
\hline & Sayı & Oran & Sayı & Oran & Sayı & Oran & Sayı & Oran \\
\hline Cumhurbaşkanı & 2 & 6 & 5 & 12 & 1 & 4 & 8 & 8 \\
\hline Başbakan & 12 & 38 & 20 & 49 & 4 & 17 & 36 & 37 \\
\hline Ana Muhalefet & 6 & 19 & - & - & 7 & 29 & 13 & 14 \\
\hline Muhalefet & 10 & 31 & 9 & 22 & 7 & 29 & 26 & 27 \\
\hline Bakanlar & - & - & 6 & 15 & 2 & 8 & 8 & 8 \\
\hline Askeri Yetkililer & - & - & - & - & - & - & - & - \\
\hline Uzmanlar & - & - & - & - & - & - & - & - \\
\hline Diğer & 2 & 6 & 1 & 2 & 3 & 13 & 6 & 6 \\
\hline Toplam & 32 & 100 & 41 & 100 & 24 & 100 & 97 & 100 \\
\hline
\end{tabular}

Her üç gazetenin haber metinlerinin oluşturulmasında birden fazla haber kaynağ1nın kullanıldığı göz önünde bulundurularak, Hürriyet Gazetesi’nin haberlerinde en fazla \%38'lik bir oranla Başbakan Binali Yıldırım’ haber kaynağı olarak kullandığı belirlenmiştir. Ardından "Muhalefet” değişkenini temsil eden Devlet Bahçeli ve parti üyelerini \%31 oranında haber kaynağı olarak kullandığı belirlenmiştir. "Ana Muhalefet” değişkenini temsil eden Kemal Kılıçdaroğlu ve parti üyelerini \%19 oranında ve \%6’lı bir orana sahip olan Cumhurbaşkanı Erdoğan’ kaynak olarak kullandığı gözlemlenmiştir. Sabah Gazetesi, 20 haberiyle \%49 oranında Başbakan'ı, 9 haberiyle \%22 oranında muhalefeti, 5 haberiyle \%12 oranında Cumhurbaşkanını haber kaynağı olarak kullandığı belirlenmiştir. Diğer gazetelerden farklı olarak bakanları en fazla oranda kullanan Sabah Gazetesi, ana muhalefeti haberlerinde kaynak olarak kullanmadığ1 gözlemlenmiştir. Sözcü gazetesi haberlerinde kaynak olarak ana muhalefeti ve muhalefeti \%29'luk bir dilimle eşit olarak kullanırken, Başbakan Yıldırım’ı 4 haberinde, bakanları 2 haberinde kaynak olarak yer verdiği belirlenmiştir.

Tablo 17. Gazetelerdeki Haber Metinlerinin Niteliği

\begin{tabular}{|l|c|c|c|c|c|c|c|c|}
\hline & \multicolumn{2}{|c|}{ Hürriyet } & \multicolumn{2}{c|}{ Sabah } & \multicolumn{2}{c|}{ Sözcü } & \multicolumn{2}{c|}{ Toplam } \\
\hline & Sayı & Oran & Sayı & Oran & Sayı & Oran & Sayı & Oran \\
\hline Bilgilendirme & 17 & 71 & 16 & 46 & 5 & 25 & 38 & 48 \\
\hline Destek & - & - & 10 & 29 & 3 & 15 & 13 & 17 \\
\hline Eleștiri & 2 & 9 & - & - & 7 & 35 & 9 & 11 \\
\hline Endişe & 2 & 8 & - & - & - & - & 2 & 3 \\
\hline İddia & - & - & 2 & 6 & 3 & 15 & 5 & 6 \\
\hline Yorum & 1 & 4 & 4 & 11 & 2 & 10 & 7 & 9 \\
\hline
\end{tabular}




\begin{tabular}{|l|c|c|c|c|c|c|c|c|}
\hline Diğer & 2 & 8 & 3 & 8 & - & - & 5 & 6 \\
\hline Toplam & 24 & 100 & 35 & 100 & 20 & 100 & 79 & 100 \\
\hline
\end{tabular}

Tablo 17'de üç ulusal gazetenin araştırmaya dâhil olan süre zarfı içerisinde haberleştirmiş olduğu haber metinlerinin niteliği; "Bilgilendirme", "Destek", "Eleştiri", "Endişe", "İddia", "Yorum" ve bunların dışında kalanlar "Diğer" değişkenleri altında analiz edilmiştir. Elde edilen verilerde Hürriyet Gazetesi'nin, 17 haberinde \%71'lik bir oranla sadece bilgilendirme işlevinde bulunduğu belirlenmiştir. Gazete haberlerinde, ikişer kez eleştiri, endişe ve diğer olarak tanımladığımız haber metinlerine ikişer kez yer verdiği görülmektedir. Sabah Gazetesi'nin, 16 haberinde \%46’lı bir oranla bilgilendirme işlevinde bulunurken, 10 gazete haberinde \%29'luk bir oranla destek işlevinde bulunduğu belirlenmiştir. Gazetenin geriye kalan 4 haberinde yorum, 3 haberinde diğer, 2 haberinde iddia işlevini gerçekleştirmiş olduğu gözlemlenmiştir. Son olarak Sözcü Gazetesi'nin haberlerinde, \%35'lik bir dilimi kapsayan eleştiriye yer verdiği belirlenmiştir. Gazete geriye kalan 5 haberinde bilgilendirme, üçer haberinde destek ve iddiaya yer verirken, 2 haberinde yoruma rastlanılmıştır.

\section{Sonuç}

Kitle iletişim araçları "haberdar etme" ve "farkına varma” görevlerini yerine getirirken toplumsal algılarımızın biçimlendirilmesinde en önemli unsurlardan biri olarak karşımıza çıkmaktadır. Medyanın aktarmış olduğu güçlü mesaj yığınlarına maruz kalan bireylerin, eylemlerinin yönlendirilmesinde kitle iletişim araçlarının doğrudan bir etkisi olduğu yapılan çalışmalarla ortaya konulmuştur. Bireyler toplumsal yaşamda meydana gelen bütün olayları kavramada yetersiz kalmaktadırlar. İçinde yaşadığımız dünyayla ilgili sahip olduğumuz bilgilerin büyük bir kısmını doğrudan deneyimler ile değil de, dolaylı olarak kitle iletişim araçları tarafından kazanıldığını ileri sürülmektedir. Medya sürekli olarak bireylerin ne hakkında düşünmeleri ne konuda fikir sahibi olmaları ve kişilerin nasıl hissetmeleri gerektiği hususunda nesneler sunarak belirli konuların üzerine dikkatleri çekmektedir. Dolayısıyla bireylerin takip etmiş oldukları medya yayınları tarafından çizilen çerçeveye bağlı olarak içinde yaşadığımız dünya herkese farklı görünecektir.

Gündem belirleme üzerine yapılan araştırmalar ilk olarak medya gündemi ile kamu gündemi arasındaki ilişkiye odaklanırken daha sonra yapılan araştırmalara siyasal gündemde konu olarak dâhil edilmiştir. Böylece üç gündem arasındaki ilişkiler ortaya konulmaya çalışılmıştır. Medya, kamu ve siyasal gündemin birbirleriyle sürekli etkileşim halinde olduklarını ve zincir halinde bulunan bu üç halka ile gündemin yaratıldığ 1 belirlenmiştir. Bu üç gündemin birbirlerini etkilediği bilinmekle beraber medya gündemi; habercilik, medya rutinleri, kurumsal ve ideolojik etkilerden kamu gündemi; herhangi bir konuda bütünleşen kişi, aile, grup ya da çıkar gruplarından ve onlar için önem taşıyan olaylardan siyasal gündem; ülke başkanları, parlamento üyeleri, bürokrasiden etkilenebilmektedir.

Gündem belirleme araştırmalarında, medya gündeminin içeriğinin belirlenmesinde etkili olan birçok unsur karşımıza çıkmaktadır. Yapılan çalışmalarda; baskı ve özel 
gruplarının çıkarları, medya içerik yapısı, sermaye sahipleri, kurumun yayın çizgisi gibi birçok değişkenle medya gündemini belirleyen unsurlar ortaya konulmuştur. Muhabirlerin çabasıyla ortaya çıan haber metinlerinin içerik yapısının oluşturulmasında; medya gruplarının örgütlenme yapısı, yayın politikaları ve haber üretim süreçlerinin en belirgin özellikler arasında yer aldığı görülmektedir. Toplumun içerisinde bulunduğu sosyal, ekonomik ve siyasal yapılarını yansitan haber metinleri, muhabirlerin ideolojileri ve gazeteciliğin temel pratikleri arasında oluşturulmaktadır. Bu haber söylemleri, son olarak medyanın ekonomi politikası üzerinden şekillendirilerek kitlelere aktarılmaktadır.

Bunların yanı sıra medya gündeminin belirlenmesinde, ani yaşanan ateşleyici olayların etkili olduğu görülmektedir. Örneğin, 15 Temmuz darbe girişimi gündeme etkili biçimde düşmüştür. Medya uzun süre bu teşebbüse, olayın faillerine ve kamudan ihraç edilen isimlere odaklanmıştır. Uluslararası yaşanan siyasal krizler, uç olaylar, ülke güvenliğini tehdit eden terör olayları medya gündeminde ilk sıralarda yer almaktadır. Halep'in bombalanması, Akdeniz'de mülteci ölümleri gibi toplumsal sorunun şiddetini gösteren "gerçek yaşam göstergeleri" de medya gündeminin oluşturulmasında oldukça etkili olmaktadır. 3 yaşındaki Aylan bebeğin kıyıya vuran cansız bedeni sadece Türk medyasında değil, dünya medyasının da gündemine oturmuştur.

Öncelikle yapılan çalı̧̧mada, medya gündeminin başkanlık sistemi tartışmaları üzerinden belirleyici olmasının başlıca sebebi, konuya dair yoğun medya ve kamuoyu ilgisinin göz ardı edilmemesi gerekliliğinden kaynaklanmaktadır. Başkanlık sisteminin uzun süre siyasetçiler arasında tartışılmasına rağmen çözüme ulaştırılamaması ve ilk defa uzlaşma sağlanarak sisteme geçiş sürecinin adımlarının atılması medya gündeminin ilk sıralarında yerini almasını sağlamıştır. İki farklı siyasi partinin mutabakat sağlaması politikada alışılmadık olay olması nedeniyle bu tarz konuların gündeme getirilmesine neden olmaktadır. Bunun yanı sıra, iletişim araçlarının haber değeri yüksek olan sınırlı haber kaynaklarına sahip olmalarının bir etkisinin de olduğunu söyleyebiliriz. Öyle ki muhabirler, medya grubunun ihtiyacı olan günlük haber miktarını sağlayabilmesi için en fazla haber yaratılan yerlerde -siyasal kurumlarda- konumlandırılması gündemin başkanlık sistemi üzerinden belirleyici olmasının diğer bir sebebini oluşturduğunu söyleyebiliriz.

Herhangi bir konunun medya gündeminde diğer konulardan sıyrılarak üst sıralara yerleştirilmesinde siyasi figürlerin ya da parti kurumlarının etkisinin oldukça yüksek olduğu görülmektedir. Haber aktörü olarak siyasi liderlerin tek başına toplumdaki herhangi bir problemi dile getirerek medya gündemine taşıyabildiği belirlenmiştir. Çalışmanın temel savı bunun üzerine biçimlendirilmiş ve elde edilen bulgular sonucunda doğrulanmıştır. Siyasi parti liderlerin gerek bireysel gerekse toplumsal talepleri medya gündeminin ilk sıralarına kolaylıkla taşıyabilme gücene sahip oldukları belirlenmiştir.

Siyasal kurumlar içerisinde en etkin enformasyon kaynağı olması nedeniyle medya, kamuoyu ve siyasetçiler arasındaki bir köprü görevini üstelendiği bilinmektedir. Medya grupları ile siyasetçiler arasında oluşan bu yakın ilişki sayesinde ister iktidar partisi olsun, isterse muhalefet partisi olsun medya gündemini belirlemede bu siya- 
si yapıların etkili oldukları tespit edilmiştir. MHP Genel Başkanı'nın grup toplantısında yapmış olduğu konuşmanın ardından siyasal gündemde ön plana çıkarılan "başkanlık sistemi" konusunun aynı zamanda gazete haber yazılarında yer edindiği görülmektedir. Böylece ulusal medya gündemi siyasi liderin yerleştirdiği bir konunun üzerinden belirlenebildiği saptanmıştır.

Farklı yayın kuruluşlarına ait Hürriyet, Sabah ve Sözcü gazetelerinde yer alan başkanlık sistemi haberlerinin incelenmesi sonucu elde edilen veriler ışığında çalışmanın varsayımlarının büyük bir oranda doğru olduğu belirlenmiştir.

İlk olarak çalışmaya başlamadan önce 1 Eylül 2016 tarihinden itibaren her üç gazetenin vitrin sayfaları ayrıntılı bir şekilde taranmış olup herhangi bir sistem değişikliği haberine 11 Ekim 2016 tarihine kadar rastlanılmadığı belirlenmiştir. Medya gündeminde yoğun bir şekilde 15 Temmuz 2016 darbe girişimi, darbe soruşturması ve ihraç edilenlerin haberlerinin yer aldığı saptanmıştır. Başkanlık sistemi tartışmalarını yeniden başlatan MHP Genel Başkanı'nın yaptığı konuşmasından itibaren her üç gazete belirlenmiş olan süre sınırlılığı içerisinde toplamda 79 adet "Başkanlık sistemi ve Anayasa değişikliği” ile ilgili haberleri gündemine taşıdığı belirlenmiştir. Siyasi liderlerin yapmış olduğu açıklamaların medya gündeminin belirlenmesinde etkili olduğu ve parti kurumlarının politikaları doğrultusunda dile getirilen problemlerin ulusal gazetelerin gündemini belirlemede tek başına yeterli olduğu varsayımları veriler ışı̆̆ında doğrulanmıştır.

Alternatif bir yönetim olarak başkanlık sistemine geçilmesi konusunun kamu gündemi içerisinde önemli bir duruma ulaşabilme koşullarının sağlanmasıyla birlikte AKP Hükümeti, MHP Genel Başkanı Bahçeli’nin yaptığı açıklamayı bir sağduyu olarak nitelendirerek medya gündemini "başkanlık tartışması” üzerinden belirlemeye devam ettiği görülmektedir. Bu süreçte en fazla haber kaynağı olarak Başbakan’a yer verildiği her üç gazeteden elde edilen verilerle doğrulanmıştır. Ülke yönetimindeki başbakanın bir konuyu ya da bir problemi kolaylıkla medya gündeminin üst sıralarına taşıyarak gazetelerde bir numaralı haber üreticisi olabileceği gözlemlenmiştir.

Medya kuruluşlarının, benimsemiş oldukları ideolojik kimlikler doğrultusunda haber metinlerini oluştururken haber aktörlerine daha kısıtlı ya da daha kapsamlı yer vermektedir. İlgili konunun haberleştirilmesinde ise olumlu ya da olumsuz, destek ya da eleştiriye yönelik bir tutum sergiledikleri varsayımı elde edilen veriler ışında doğrulanmaktadır.

Sabah Gazetesi, araştırmaya konu olan süre zarfında yayınladığı haberlerinde iktidar parti politikalarına ve liderlerine sayıca fazla yer verdiği, yayımlanan haberlerin yorum içeren destek odaklı haberlerden oluşturulduğu belirlenmiştir. Gazete, Ana Muhalefet liderlerinin haberlerine sayıca az yer vererek, araştırmaya dâhil edilen konu ise eleştiriye ve yoruma dayalı, olumsuz bir yönde ele alındığı belirlenmiştir.

Ulusalcı yayın politikası benimseyen Sözcü Gazetesi’nin, ilk sayfalarında iktidar parti grubunun başkanlık sistemiyle ilgili politika ve liderlerine sayıca fazla yer verildiği fakat ilgili konunun haberleştirilmesinde eleştiriye odaklı ve yoruma dayalı, olumsuz bir biçimde ele alındığı belirlenmiştir. Gazete, AKP ve MHP liderinin politikalarını 
eleştiriye dayalı olumsuz yönde ele alırken, Ana Muhalefet partisinin başkanlık sistemine dair politikalarını olumlu yönde ele aldığı tespit edilmiştir. Bunun yanı sıra Halkların Demokratik Partisi’nin (HDP) başkanlık sistemiyle ilgili politikalarına yer verilmediğine rastlanılmıştır.

Kitle gazetesi olarak bilinen Hürriyet Gazetesi haberlerinde AKP, MHP, CHP ve HDP’nin siyasi politikalarına tarafsız yaklaştığı ve gazete'nin haberlerini kurgularken en fazla bilgilendirme kaygısı güttüğü belirlenmiştir.

İktidar partisinin politikalarına yakın duruş sergileyen Sabah Gazetesi, AKP ve MHP arasında uzlaşma yaşaması sonucu, MHP Genel Başkanı'na gazetenin ilk sayfalarında sayıca fazla yer verdiği, haberlerinde destek ve yoruma dayalı, olumlu bir yönde ele aldığ 1 belirlenmiştir. Sözcü Gazetesi'nin ise AKP ve MHP arasında mutabakat sağlanması sonucu, MHP Genel Başkanı'nı, eleştiri ve yoruma dayalı, olumsuz bir yönde ele aldığı tespit edilmiştir. Son olarak kamuoyunun sistem değişikliğine karşı olan hassasiyeti haber metinleriyle Türk basınına taşındığı belirlenmiştir.

\section{Kaynakça}

“2023 Siyasi Vizyon”. Son güncelleme 10 Mayıs 2017. http://www.akparti.org.tr/site/ akparti/2023-siyasi-vizyon\#bolum_.

“7 Haziran 2015 tarihli seçim beyannamesi”. Son güncelleme 10 Mayıs 2017. www. akparti.org.tr/upload/documents/2015-secim-beyannamesi-20nisan.pdf.

"Anayasa değişikliği paketi kabul edildi”. Sabah internet sitesi. 10 Mayıs 2007. http://arsiv.sabah.com.tr/2007/05/10/haber,BB63A2F0C5114812B85DF34520DA7C36.html (Erişim tarihi 10 Nisan 2017).

“Anayasa Uzlaşma Komisyonu Çalışmalarına İlişkin Sonuç Dokümanları”. Son güncelleme 10 Mays 2017. https://anayasa.tbmm.gov.tr/calismalara_iliskin_ belgeler.aspx.

Akgün, Mert Hüseyin. "Başkanlıktan Cumhurbaşkanlığı Sistemine: 2012 ve 2016 Ak Parti Anayasa Önerileri”. https://setav.org/assets/uploads/2017/01/ Perspektif163.pdf. (Erişim 10 Mayıs 2017).

Basın açıklaması. "Yeni Yıl Mesajı". https://www.tccb.gov.tr/basin-aciklamalariahmet-necdet-sezer/1720/6491/yeni-yil-mesaji.html. (Erişim 10 Mayıs, 2017).

Bila, Fikret. “Erdoğan ve Gül' ün Yaklaşımları”. Milliyet. 21 Nisan 2003.

Cumhuriyet. Erdoğan Krallık İstiyor. 24 Nisan 2004.

Duman, Selçuk. “Türkiye İçin Başkanlık Sistemi Değerlendirmeleri”, Yeni Türkiye Dergisi. 51 (2013).

Fedayi, Cemal. "Mazi, Hal ve İstikbal Boyutlarıyla Başkanlık Sistemi”. Yeni Türkiye Dergisi. 51 (2013).

Gönenç, Levent. “Türkiye’de Hükümet Sistemi Değişikliği Tartışmaları Olanaklar ve Olasılıklar Üzerine Bir Çalışma Notu”. Teoman Ergül (der.). Başkanlık Sistemi. Ankara: Türkiye Barolar Birliği Yayınları, 2005.

Gönenç, Levent. “Türkiye’de Hükümet Sistemi Tartışmalarına Kısa Bir Bakış ve Mevcut Hükümet Sisteminin Niteliği”. Türkiye Ekonomi Politikaları Araştırma Vakf1, Nisan 2011. 
Hans, Mathias Kepplinger. Medya Etki Araştırmaları. Çev. Murat S. Çebi. Ankara: Alternatif Yayınları, 2003.

Hürriyet. Şahin'den başkanlık sistemine destek. 22 Nisan 2003. http://www.hurriyet. com.tr/sahinden-baskanlik-sistemine-destek-141935 (Erişim 12 Nisan 2017).

Kılınç, Doğan. “Türkiyede Bitmeyen Tartışma: Hükümet Sistemi Üzerine Değerlendirmeler”. Gazi Üniversitesi Hukuk Fakültesi Dergisi. 20/1 (2016): 447 510.

Kurban, Samed. "Başkanlık Sisteminden Beklentiler ve Türkiye”. Yüksek Lisans Tezi. Dumlupınar Üniversitesi, 2014.

Küçükoba, Gamze. "Başkanlık Sistemi ve Türkiye’ye Uygunluğu Sorunsalı”. Yüksek Lisans Tezi. Dicle Üniversitesi, 2014.

Milliyet. Başkanlık İstiyor. 21 Nisan 2003.

Milliyet. Baykal'dan Erdoğan’a Haddini Bil. 23 Nisan 2003.

Oder, Bertil Emrah. “Türkiyede Başkanlık ve Yarı Başkanlık Rejimi Tartışmaları: 1991- 2005 Yilları Arasında Basına Yansıyan Öneri ve Tepkilerden Kesitler”. Teoman Ergül (der.). Başkanlık Sistemi. Ankara: Türkiye Barolar Birliği Yayınları, 2005.

Onar, Erdal. “Türkiye’nin Başkanlık ya da Yarı Başkanlık Sistemine Geçmesi Düşünülmeli mi?”. Teoman Ergül (der.). Başkanlık Sistemi. Ankara: Türkiye Barolar Birliği Yayınları, 2005.

Şıvgın, Halil. Türkiye İçin Umut Krizden Çıkış Yeniden Yapılanma ve Başkanlık Sistemi. Ankara: Türk Dünyasında Demokrasiyi Geliştirme Vakfı Yayınları, 1997.

TBMM. “10.5.2007 Tarihli ve 5660 Sayılı Türkiye Cumhuriyeti Anayasasının Bazı Maddelerinde Değişiklik Yapılması Hakkında Kanun ve Anayasanın 89 uncu ve 104 üncü Maddeleri Gereğince Cumhurbaşkanınca Bir Daha Görüşülmek Üzere Geri Gönderme Tezkeresi ile Anayasa Komisyonu Raporu (1/1368)". https://www.tbmm.gov.tr/sirasayi/donem22/yil01/ss1433m.htm.

Terkan, Banu. Gündem Belirleme Medya ve Siyasal Gündem Üzerine Bir Çalıșma. Konya: Tablet Kitapevi, 2005.

Tosun, Gülgün ve Tanju Tosun. Türkiye’nin Siyasal İstikrar Arayışı Başkanlık ve Yarı Başkanlık Sistemleri. İstanbul: Alfa Yayınları, 1999.

Turan, İlter. "Başkanlık Sistemi Sevdası: Zayıf Temelli Bir Özlem”, Teoman Ergül (der.). Başkanlık Sistemi. Ankara: Türkiye Barolar Birliği Yayınları, 2005.

Uluşahin, Nur. “Türkiye'de Hükümet Sisteminin Niteliği ve Rejimin Başkanlık Sistemine Kaymasının Getireceği Tehdit ve Tehlikeler". Hukuk ve İktisat Araştırmaları Dergisi. 3/1 (2011): 29-38.

Yazıcı, Serap. Başkanlık ve Yarı-Başkanlık Sistemleri Türkiye İçin Bir Değerlendirme, İstanbul: İstanbul Bilgi Üniversitesi Yayınları, 2013.

Yılmaz, Sait. “Başkanlık Sistemi; ABD, Türkiye’ye Örnek Olabilir mi?”. Yeni Türkiye Dergisi. 51 (2013).

Yüksel, Erkan. Medyanın Gündem Belirleme Gücü. Konya: Çizgi Kitapevi Yayınları, 2001. 


\title{
Reflection of the Presidential System Discussions During April 16 Referendum in Turkish Press
}

\author{
EZGI ÇAKIR
}

\begin{abstract}
From historical point of view on Turkish politics, the discussions of alternative system of government which began with Ozal and extended to Demirel's tenure, statements made by political leaders have taken place on Media agenda. Finally, intense discussions continued during the period AK Party governement which led to the April 16 referendum. News actors and Political leaders have great influence especially on the creation of the presidential system agenda, as it is assumed that news actors are more restricted or comprehensive, positive or negative in the direction of the ideological publication line they have adopted in news covered by media organizations. In this context, based on Agenda-setting theory, period before the April 16 referendum and between October 11, 2016 and December 10, 2016, on media coverage of the presidential system discussions will be examined by content analysis method which includes qualitative and quantitative evaluation on the first pages of Sabah, Hürriyet and Sözcü newspapers.
\end{abstract}

Keywords: Presidential system, Agenda setting, Referendum. 